\title{
Making Democratic-Governance Work: The Consequences for Prosperity
}

\section{Citation}

Norris, Pippa. 2011. Making Democratic-Governance Work: The Consequences for Prosperity. HKS Faculty Research Working Paper Series RWP11-035, John F. Kennedy School of Government, Harvard University.

\section{Published Version}

http://web.hks.harvard.edu/publications/workingpapers/citation.aspx?Publd=7967

\section{Permanent link}

http://nrs.harvard.edu/urn-3:HUL.InstRepos:5131502

\section{Terms of Use}

This article was downloaded from Harvard University's DASH repository, and is made available under the terms and conditions applicable to Other Posted Material, as set forth at http:// nrs.harvard.edu/urn-3:HUL.InstRepos:dash.current.terms-of-use\#LAA

\section{Share Your Story}

The Harvard community has made this article openly available.

Please share how this access benefits you. Submit a story.

Accessibility 


\section{Making Democratic-Governance Work: The Consequences for Prosperity Faculty Research Working Paper Series}

\section{Pippa Norris}

Harvard Kennedy School

\section{September 2011}

\section{RWP11-035}

The views expressed in the HKS Faculty Research Working Paper Series are those of the author(s) and do not necessarily reflect those of the John F. Kennedy School of Government or of Harvard University. Faculty Research Working Papers have not undergone formal review and approval. Such papers are included in this series to elicit feedback and to encourage debate on important public policy challenges. Copyright belongs to the author(s). Papers may be downloaded for personal use only. 


\title{
Making Democratic-Governance Work: The Consequences for Prosperity ${ }^{(*)}$
}

\section{Pippa Norris}

\begin{tabular}{ll}
\hline McGuire Lecturer in Comparative Politics & Visiting Professor of Government and IR \\
Kennedy School of Government & The University of Sydney \\
Harvard University & Department of Government \\
Cambridge, MA 02138 & NSW, 2006 \\
Pippa Norris@,Harvard.edu & $\underline{\text { Pippa.norris@,sydney.edu.au }}$ \\
www.pippanorris.com & $\underline{\text { www.arts.sydney.edu.au }}$ \\
\hline
\end{tabular}

\begin{abstract}
Does democratic governance expand wealth and prosperity? There is no consensus about this issue despite the fact that for more than half a century, rival theories about the regime-growth relationship have been repeatedly tested against the empirical evidence, using a variety of cases, models and techniques. To consider the issues, Part I of this paper reviews and summarizes theories why regimes are expected to influence economic growth directly, either positively or negatively. After considering these debates, Part II discusses the technical challenges facing research on this topic and how it is proposed to overcome these. Part III presents the results of the comparative analysis for the effects of democratic governance on economic growth during recent decades. The descriptive results illustrate the main relationships. The multivariate models check whether these patterns remain significant after controlling for many other factors associated with growth, including geography, economic conditions, social structural variables, cultural legacies, and global trends. The evidence supports the equilibrium thesis suggesting that regimes combining both liberal democracy and bureaucratic governance are most likely to generate growth, while by contrast patronage autocracies display the worst economic performance. The conclusion considers the implications.
\end{abstract}

Keywords: Political regimes, democracy, governance, economic growth, development

Paper for Panel 11-22 "Democratic Institutions and Social Welfare", 4.15pm Thursday September $1^{\text {st }}$ 2011, the annual meeting of the American Political Science Association, Seattle. 
Does democratic governance expand wealth? This question has long been at the heart of intense debates in the social sciences and among policymakers. Since billions of people continue to live in poverty, understanding this issue is vitally important. In recent decades, international organizations have devoted growing resources to strengthening regimes; hence the World Bank now emphasizes that countries with so-called 'good governance' are more likely to attract investment in human and physical capital, and thus generate the conditions thought favorable to long-term prosperity. ${ }^{1}$ The Bank's programs have worked with country partners to strengthen mechanisms designed to strengthen the transparency of decision-making and the accountability of public officials, including control of corruption, legal mechanisms securing property and contractual rights, the independent media and civil society organizations, the conditions of basic security and order, and capacity building of public sector management. ${ }^{2}$ Elsewhere this perspective has influenced development agencies, notably the United States Millennium Challenge Account, which uses the quality of governance as a condition for the allocation of additional aid. ${ }^{3}$ Similarly the assumption that democratic governance generates both growth and welfare (and thus potential achievement of the Millennium Development Goals) has strongly influenced strategic priorities within many United Nations agencies and bureaus. ${ }^{4}$ Hence the United Nations Development Programme used to focus on providing technical assistance and capacity building for public administration reform; since 2002, however, work on democratic governance has expanded in scope and size to the point where this focus area absorbs almost half the organization's total budget. UNDP supports one in three parliaments in the developing world and an election every two weeks. In 2010, UNDP helped over 130 countries and devoted US\$1.18 billion in resources to democratic governance, making UNDP the world's largest provider of democratic governance assistance. ${ }^{5}$

Given this investment of resources, it is vitally important to understanding the role of regime institutions in spurring economic growth, improving living standards and alleviating poverty. For more than half a century, rival theories about the regime-growth relationship have been repeatedly tested against the empirical evidence, using a variety of cases, models and techniques. Scholars have examined evidence throughout the third wave era and by now a substantial research literature has now emerged investigating this relationship, both in regional studies as well as comparisons of global trends. ${ }^{6}$ Despite repeated and imaginative attempts to do so, many technical challenges arise when seeking to establish conclusive proof. Partial agreement is starting to emerge about some of the observable empirical regularities, but even here the complex reciprocal linkages between regime institutions and growth means that consensus is far from complete. For some, neo-liberal 'good' governance institutions such as property rights and rule of law (but not democracy) do indeed facilitate growth in per capita GDP. ${ }^{7}$ For others, however, growth is the key driver of the quality of democratic governance. ${ }^{8}$ For still others, any relationship is modified by certain conditions, whether the specific type of constitutional design, how long institutions have been established, a specific threshold level of development, or the type of societal culture within which institutions are embedded. Studies of the relationship between democracy and growth generate results which are highly sensitive to technical specifications and the comparative framework, hence findings have failed to prove robust when replicated using a different range of nations or with models employing alternative indicators and methods. ${ }^{9}$ Moreover claims that 'institutions matter' are constructed at a highly abstract level and theories identifying the intermediate mechanisms linking regimes and growth, and thus our 
capacity to offer policy-relevant recommendations, remain under-specified and poorly understood. Equally importantly, most studies have analyzed the impact of either democracy or governance, but the comparison of both of these twin phenomena has been neglected. For all these reasons, previous research needs to be revisited to establish more robust and precise generalizations.

The structure of this paper proceeds as follows. Part $I$ reviews and summarizes theories why regimes are expected to influence economic growth directly, either positively or negatively. After considering these debates, Part II discusses the technical challenges facing research on this topic and how it is proposed to overcome these. Part III presents the results of the comparative analysis for the effects of democratic governance on economic growth during recent decades. The descriptive results illustrate the relationship between regimes and growth. The multivariate models check whether these patterns remain significant after controlling for other factors associated with growth and governance, including geography, economic conditions, social structural variables, cultural legacies, and global trends. The evidence supports the equilibrium thesis suggesting that regimes combining both liberal democracy and bureaucratic governance are most likely to generate growth, while by contrast patronage autocracies display the worst economic performance. The conclusion in Part IV summarizes the findings and implications.

\section{I: Theories linking regimes with economic growth}

Several distinctive theoretical perspectives can be identified concerning the regime-growth relationship. Skeptics believe that regime institutions are unable to exert significant independent effects on growth (the null hypothesis) compared with many standard factors commonly emphasized in the research literature. While societal modernization is expected to strengthen processes of democratization and investment in the quality of governance institutions, in the skeptical view the reverse relationship does not hold. These views are challenged by equilibrium theory, which posits that economic growth is strengthened by regimes combining liberal democratic institutions (reinforcing channels of electoral accountability) with bureaucratic governance (and thus state capacity for effective macro-economic management). These claims are compared against those of other scholars who offer a number of reasons why the institutions of either governance (for realists) or those of liberal democracy (for idealists) are expected to influence income. There is no single perspective within each of these schools of thought. Several potential linkage mechanisms are suggested in the previous literature, each emphasizing a different underlying connection. After reviewing the arguments, the cross-national time-series evidence allows us to test each of these accounts, comparing equilibrium theory against its rivals.

\section{The skeptical 'null hypothesis'}

The traditional economics literature seeking to identify the 'deep' or 'fundamental' determinants of economic performance suggests that growth is affected by a multitude of complex factors. Economists typically emphasize levels of investment in human and physical capital and societal infrastructure (schools, roads, communications), openness to trade (and thus export-led growth of goods and commodities), geography (climate, location, type of agriculture, risk of tropical disease, and access to neighboring markets), the diffusion of access to technological innovations, the distribution of natural resources (such as minerals, oil and gas), social structure (including the size of the labor force, levels of social inequality and 
ethnic divisions), and the cultural values which predominate in any society. ${ }^{10}$ There is a broad consensus that countries which invest more, develop new technologies, and have better infrastructures are expected to grow more successfully.

By contrast, the precise role of formal institutions as part of this process, and which types of institutions are important, remains under dispute in the contemporary research literature. Ever since Douglas North's seminal contribution, some economists claim that 'institutions rule', emphasizing the contribution of rule of law, private property rights and control of corruption to growth. ${ }^{11}$ An influential study by Acemoglu, Johnson, and Robinson argues that in former European colonies, colonial settler mortality rates serve as a proxy for the quality of contemporary political institutions. $^{12}$ The conditions in the colonies, they reason, were vital for early institution-building, laying the foundations for modern contract law, secure property rights, and human capital, all of which provide the foundations for flourishing markets and effective states. Yet several scholars reverse their interpretation of the relationship, on the grounds that institutions such as effective and clean administration in the public sector, rule of law, and respect for property rights are probably the consequence, rather than the cause, of economic growth. ${ }^{13}$ Glaeser et al argue that the Europeans who settled in the new World may have brought their human capital with them (the skills and capacities derived from literacy and schooling), rather than their legal institutions. Since human capital is a strong predictor of economic growth, they argue that predictors of settlement patterns are not valid instruments for political institutions. ${ }^{14}$ Charron and Lapuente argue that any relationship runs from growth to governance; growing prosperity is thought to expand the resources available to invest in the quality of bureaucratic governance and the administration of public services, as well as public demands for these services. ${ }^{15}$ Therefore although 'good governance' has now become fashionable in the international development community, the robustness of the empirical findings claiming that institutions matter for income continues to be debated, compared with many other deep drivers of prosperity.

At the same time, many doubt whether democracy exerts a significant independent effect upon economic prosperity; democratic regimes can be rich (Sweden) or poor (Mali). Similarly autocracies vary from the resurgent growth and experienced by China and Viet Nam to the economic stagnation or decline which is evident in North Korea or Zimbabwe. Support for the skeptical perspective is found in much of the empirical evidence. Thus although some research reports that the institutions of liberal democracy have a positive impact on economic growth, most studies suggest a negative relationship, or indeed no significant relationship at all. ${ }^{16} \mathrm{~A}$ widely cited early study by Robert Barro reported that growth was strengthened by maintenance of the rule of law, free markets, small government consumption, and high human capital. Once models control for these kinds of variables, and the initial level of real per-capita GDP was held constant, then the overall additional effect of liberal democratic regimes on growth proved weakly negative. ${ }^{17}$ The skeptical perspective was reinforced by one of the most comprehensive studies, by Adam Przeworski, Michael Alvarez, José Antonio Cheibub, and Fernando Limongi, which compared the experience of economic and political development in 141 countries from 1950 to $1990 .{ }^{18}$ Democratic and autocratic regimes were classified according to Schumpeterian rules of electoral contestation. The study concluded that according to this measure, democracies proved no better (but also no worse) than dictatorships at generating economic growth. Among poor countries, as well, the type of regime 
made no difference for growth. "In countries with incomes below $\$ 3000$, the two regimes have almost identical investment shares, almost identical rates of growth of capital stock and of labor force, the same production function, the same contributions of capital, labor, and factor productivity to growth, the same output per worker, the same labor shares, and the same product wages... Regimes make no difference for growth, quantitatively or qualitatively." 19 The most recent comprehensive review of the research literature, by Doucouliagos and Ulubasoglu, compared and summarized 84 studies published on the regime-growth relationship. ${ }^{20}$ Not surprisingly, their meta-analysis noted that estimates of the regime-growth relationship differed across this wide range of studies, due to varied data sources, techniques, control variables, country coverage, and time periods. Overall, however, the study concluded that liberal democracy exerts no direct impact on prosperity, either positively or negatively. Some indirect regime effects were observed, however, since liberal democracies invest more in human capital and have greater political stability, both of which are thought to strengthened growth. If the skeptical view is indeed correct, then the empirical evidence should demonstrate that the prior type of regime makes little significant difference, positive or negative, to subsequent levels of economic growth.

\section{The effects of governance on growth}

The skeptical view about the positive role of regimes for growth has not been confined to academic studies; in the past, it also permeated the international development community. During the 1970s and 1980s, the first-generation 'Washington Consensus' advocated by the agencies of global finance, based on neoclassical theories in political economy, explained prosperity as a product of market forces; countries seeking to expand production output and export-led growth were advised to end protectionism and open borders to international trade, attract investment capital, allow competitive exchange rates, develop human capital, adapt to technological progress, deregulate the economy, and enlarge the labor force. In the neo-classical view, the state was regarded as hindering growth in the private sector if it ventured beyond strictly minimal Smithsonian functions of providing security, infrastructure, and protection of property rights. The predatory or bloated state was seen as problematic for growth, especially macroeconomic policies involving public sector ownership of industry, massive budget deficits, negative interest rates, protectionist restrictions on free trade, over-regulation, endemic corruption, and inadequate basic public services. ${ }^{21}$ Tax reform, privatization, trade liberalization, anticorruption measures, and fiscal austerity were the prescribed medicine to cure these ailments. It was believed that the state had to get out of the way, to let unfettered markets achieve growth most efficiently. In the rush to liberalize public-sector ownership and shrink the size of the state, little attention was paid to the capacity of government, whether to regulate the privatization process and prevent the emergence of new oligopolies, to provide security, to manage the delivery of other basic goods and services, to plan and implement policies, and to enforce laws.

The first-generation Washington consensus therefore held that good economic performance required liberalized trade, macroeconomic stability, and getting prices right. In subsequent years, however, the revised second-generation Washington consensus came to acknowledge the dangers of radical structural adjustment, including growing social inequality, market failures, and corruption, and the important positive role of the state in development. ${ }^{22}$ Many factors contributed towards this revised philosophy. Latin American countries, which had embraced the menu of liberalization, often failed to achieve stable and equitable economic growth. 
Economists in the region started to address the institutional reforms needed to tackle social inequality and substantial improvements in living standards for the poor. ${ }^{23}$ Experience in Eastern Europe, especially Russia, demonstrated that shock therapy and selling off public sector assets in countries lacking rule of law and control of corruption merely transferred state power to business oligarchs and reinforced crony capitalism. The fall of the Berlin Wall, and transitions from autocracy elsewhere in the world, spurred renewed interest in understanding the economic consequences of processes of democratization and constitutional arrangements, as well as providing new opportunities for institutional reform. The 1997 Asian economic crisis, in countries which had liberalized their economies, created new challenges to the standard prescriptions. ${ }^{24}$ Most recently, doubts about the wisdom of unregulated markets have been reinforced by the financial downturn catalyzed by the bursting housing bubble and banking crisis in the United States, before quickly infecting debtridden economies in Mediterranean Europe and beyond. ${ }^{25}$

Neo-liberal claims for 'good governance'

The second-generation Washington Consensus, emerging in response to all these developments, recognized that effective state institutions and the quality of governance can function as 'deep drivers' which supplement markets and thereby also contribute positively towards economic growth. ${ }^{26}$ The good governance perspective became popular following seminal work published during the early-1990s by Douglas North, the Nobel prize-winning economist, leading scholars of development to rediscover the importance of 'institutions', understood as both formal legal regulations and informal patterned social interactions, cultural traditions, and social norms determining mechanisms of social cooperation and how authority is exercised. ${ }^{27}$ The substantial body of empirical literature which has emerged in economics in recent decades has reinforced the claim that certain types of neo-liberal governance institutions are critical for development. Research started to explore some of the empirical evidence, including a seminal paper by Mauro documenting the links between corruption and growth. ${ }^{28}$ This paper stimulated a substantial body of work replicating and expanding these core findings, using many types of economic indices and measures of corruption. ${ }^{29}$ Another early study by Knack and Keefer reported that the International Country Risk Guide (ICRG) ratings of the quality of governance were directly related to growth of per capita income. ${ }^{30}$

This work highlighted the need for cross-national and time-series indicators capable of monitoring institutional quality. From 1996 onwards, Daniel Kaufmann, Aart Kraay, and Massimo Mastruzzi at the World Bank Institute developed composite estimates for all countries worldwide covering six dimensions of so called 'good governance', including perceptions of rule of law, control of corruption, voice and accountability, regulatory quality, government effectiveness, and political stability, derived from expert polls and public opinion surveys conducted by multiple organizations. ${ }^{31}$ This evidence seemed to provide empirical support for the neoliberal perspective emphasizing the importance of good governance institutions, especially those strengthening control of corruption, property rights, and rule of law. In a series of papers, Daniel Kaufmann and colleagues have drawn upon the World Bank Institute indices as evidence to argue that 'good governance' generates substantial pay-offs for the economy: "A country that improves its governance from a relatively low level to an average level could almost triple the per capita income of its population in the long-term." 32 Acemoglu, Johnson, and Robinson strengthened this argument, using colonial settler mortality rates serve as instrument for the quality of contemporary 
political institutions..$^{33}$ Using this measure, Rodrik, Subrahanian and Trebbi also conclude that rule of law and security of property rights are both deep determinants of economic growth, controlling for the effects of geography and trade. ${ }^{34}$ These particular institutions are believed to underpin free markets, investor confidence, and contract enforcement. Neo-liberals therefore emphasize that income growth is facilitated by specific types of institutions which are thought to reduce the risks and barriers that investors face in the marketplace. If this claim is true, then growth rates should be strongly linked with several specific indices of 'good' governance, in particular the WBI estimates of Rule of Law, Property Rights, and Control of Corruption.

\section{The effects of state capacity on growth}

Yet good governance is an abstract and vague term which is open to alternative interpretations. Following the 'institutional turn' in economics, other leading scholars have renewed the emphasis on the role of formal rules, but good governance has been interpreted from a more Keynesian or social democratic perspective. Hence the Nobel prize-winner Joseph Stigletz advocated a more interventionist role for the state in the economy, using the strategic levers of regulatory institutions, social insurance programs, fiscal and monetary policies, above and beyond ensuring the conditions for free markets through protecting private property rights and rule of law. ${ }^{35}$ Francis Fukuyama led realist thinking by emphasized the urgent need for state-building and well-functioning public administration, on the grounds that weak states are the source of many of the world's problems, from poverty to AIDS, terrorism and drugs. ${ }^{36}$ Public sector reform was needed, Fukuyama argues, for effective state capacity, even though the scope and functions of the state needed to be limited. By contrast, Fukuyama argues that democracy and human rights do not deserve equal priority for the international development community, except perhaps as a way to legitimize states. ${ }^{37}$

If it is recognized that governments need to play an effective role in economic development -- through regulating the market economy, implementing laws and policies, planning budgets, and managing the delivery of public goods and services -- then their ability to do so rests, in large part, upon the professional skills, procedural culture, and technical capacity of the public sector. Presenting empirical support this view, Evans and Rauch documented the link between estimates of the quality of 'Weberian bureaucracy' and economic growth. The study compared almost three-dozen developing societies from 1970 to 1990, measuring perceptions of the quality of bureaucratic governance from an expert survey. The results showed that states where the civil service in the core economic agencies had meritocratic recruitment processes, and predictable career ladders, enjoyed greater prosperity, after controlling for initial levels of per capita GDP and human capital. ${ }^{38}$

Many case studies are also often cited to support the claim that the implementation of effective development policies requires competent public administration and a strong and effective state. This argument is believed to be exemplified by the remarkable growth and rapid industrialization enjoyed in the East Asian tiger economies of Taiwan, Singapore, China, and South Korea, leading some observers to posit a sequential process of 'economic development first, democracy second'. ${ }^{39}$ The case of Singapore is commonly thought to illustrate the Asian model of development, combining both economic success and social stability, and thus the presumed advantages of bureaucratic autocracies. Singapore has become one of the most affluent nations around the world, ranked 23 ${ }^{\text {rd }}$ highest on the 2009 Human 
Development Index, just behind Germany and ahead of Greece, Israel and Portugal. The Singapore economy, built upon the service-sector, particularly finance, banking, investment, and trade, has forged ahead despite a lack of natural resources. In 2009, Singapore produced a per capita GDP of around $\$ 37,000$ (in PPP), similar to Italy and Japan. An autocracy ruled by one predominant party, and with limited political rights and freedoms, bureaucratic governance in the island state is widely regarded as both efficient and effective. 40

China is an even more striking case, enjoying an average annual growth rate of 10 percent over the last three decades, a rate maintained despite the 2008 global financial crisis which has afflicted advanced economies, especially the United States and the euro zone. In 1980, the average per capita income in China was \$251 (with the nation ranked $4^{\text {th }}$ last worldwide). ${ }^{41}$ By 2010 , this figure had risen to $\$ 7,240$ (ranked 89th from the bottom). China is widely regarded as challenging the standard neo-liberal conventional wisdom that free markets, state deregulation, and secure private property rights are vital for growth. ${ }^{42}$ The political stability found in bureaucratic autocracies is believed to encourage the process of rapid industrialization and thus facilitate sustainable economic growth. Yet the evidence for administrative competence in East Asian states does not always tell a consistent story supporting these claims; the Republic of Korea, for example, experienced serious problems of corruption and crony capitalism for many decades during its long period of economic development, although in recent years this has greatly diminished. ${ }^{43}$ If the core argument is correct, however, it suggests that the quality of bureaucratic governance in any country should significantly affect subsequent levels of economic growth.

\section{The effects of democracy on growth}

\section{Accountability: Elections reward competent economic management}

Skeptical claims that democracy fails to exert an independent effect upon economic development, compared with other structural determinants, are also challenged by idealist arguments. The most common argument in this perspective suggests that democracies are usually more successful at generating economic growth since competitive elections provide an automatic fail-safe mechanism for removing incompetent leaders; governing parties perceived by citizens as successful at managing the economy are usually returned to office, while ineffective administrations are kicked out. Halperin, Siegle and Weinstein argue that in this regard democracies have a 'self-correcting mechanism'. ${ }_{4}$ By contrast, no such regular and peaceful channel exists in autocracies to remove inept, repressive, or venal leaders. As Fukuyama points out, autocracies have variable economic performance; states may be ruled by a Lee Kwan Yew but they may also be run by a Mobutu or a Marcos or a Gaddafi. ${ }^{45}$

The accountability argument builds upon several well-established theories in the literature, including (i) the Schumpeterian conception of democracy, emphasizing the role of elections as core mechanisms in democracy for the expression of public preferences, government accountability, and political responsiveness; (ii) Downsian theories suggesting that rational voters cast ballots seeking to maximize their utility, as well as (iii) theories of retrospective voting, emphasizing that in democratic states, citizens evaluate the economic performance of the governing party and leader, rewarding or punishing them accordingly at the ballot box. ${ }^{46}$ This last line of thought suggests that particular elections in each country can revolve around the government's record on a wide range of issues on the policy agenda but overall many 
contests are thought to be won or lost based on public evaluations of the governing party or parties' competence in managing bread-and-butter economic conditions. ${ }^{47}$ Poor government results at the ballot box have commonly been attributed to conditions of unemployment, inflation, or poor growth, in contests where "it's the economy, stupid". ${ }^{48}$ Vote-seeking politicians thus have a strong incentive to manage the economy effectively and to offer alternative policies which appeal to the majority of the electorate. ${ }^{49}$ Parties and leaders demonstrating a competent record are expected to be most consistently returned to steer the nation's economy, while those with a poor performance are usually less successful in gaining power. By contrast, autocrats face no such electoral sanction; citizens have little power to get rid of ineffective leaders, short of violent means, in countries such as Zimbabwe, Somalia and Libya, despite public disaffection with declining incomes, endemic poverty, and worsening living standards. ${ }^{50}$ If these claims are true, when tested against the empirical evidence, levels of democratization should predict subsequent levels of economic growth.

Some limited evidence supports this claim; for example Halperin, Siegle and Weinstein compared the economic performance of poorer societies (defined as those below $\$ 2000$ per capita) from 1960 to 2005 and found that democracies consistently enjoyed higher per capita growth rates than autocracies. Moreover when all countries are considered, they report that democracies have realized consistently higher levels of economic growth than autocracies during the last five decades. ${ }^{51}$ Yet many other characteristics of democratic societies, not controlled in their models, may be driving these observations. The claim that democratic regimes are more positive for growth has also been strongly challenged. Hence drawing upon experience of development in Latin America, Guillermo O'Donnell, argued that the early stages of any democratic transition in the region were often characterized by weaker governance capacity, and thus greater instability and uncertainty, inflationary pressures on the state, and a rise in distributional conflict, heightening the risks facing international investors. ${ }^{52} \mathrm{By}$ contrast he emphasized that states with effective bureaucracies and strong executives had the capacity to respond promptly and decisively when managing the economy, especially during crisis conditions.

\section{Do democracies strengthen human capital with indirect effects on growth?}

Another reason why the type of regime may affect growth indirectly, idealists suggest, is through investment in the labor force. Human capital is widely regarded as important for growth; higher levels of literacy, schooling and vocational training produce a more productive workforce, a process which is thought especially important given the demands of modern technologies and the need for skills in service sector jobs. ${ }^{53}$ Several studies have now reported that liberal democracies invest more in primary and secondary education and vocational training - and they also achieve better attainment outcomes. ${ }^{54}$ According to Halperin, Siegle and Weinstein, for example, among low-income economies, democracies have typically realized secondary school enrollment levels $40 \%$ higher than autocracies. ${ }^{55}$ Moreover studies relate education with growth; based on a panel study of 100 countries from 1965 to 1995 , Barro reports that growth is affected by the average years of school attainment of adult men at secondary and higher levels. ${ }^{56}$ The human capital argument focuses upon schooling attainment, literacy, and tertiary training, all thought important for a productive and skilled labor-force. If liberal democracies do invest more in human capital, and if this process has an indirect effect on prosperity, as several studies suggest, then the type of democratic regime combined with the gross enrollment rates of secondary-level education should expand wealth. Nevertheless this claim also remains 
under debate in the literature. In particular, questions remain when determining the direction of causality in any relationship, since the classic 'Lipset' thesis claims that the expansion of education and literacy are some of the key features of industrial societies which facilitate democratization. Barro confirmed that access to primary schooling, and a smaller gender gap in educational attainment, both strengthened the propensity for democracy. ${ }^{57}$ Hence it is critical to try to disentangle any complex correlations linking the type of regime, levels of human capital, and income growth.

Do power-sharing democracies promote growth?

Several scholars emphasize that beyond the regime, the specific type of democratic institutions matters for accountability. Constitutional arrangements vary among democracies and major contrasts include those arising among majoritarianplurality, mixed, or proportional electoral systems; presidential, mixed, or parliamentary executives; single party or coalitional party governments; and federal or unitary states. Each of these categories also contains many important variations, for example PR electoral systems differ by their use of open or closed lists, the level of any formal vote threshold, and the type of vote formula. ${ }^{58}$ Similarly the constitutional powers and responsibilities of presidents and prime ministers vary substantially, especially in 'mixed' executives which combine both roles. Rather than the type of regime, several scholars emphasize that the particular constitutional arrangements matter for economic performance. ${ }^{59}$ In a series of studies, Persson and Tabellini suggest that constitutional variations such as states with presidential or parliamentary executives influence economic performance, including fiscal policies, trade policies, and levels of public spending, and thus have an indirect effect upon growth. They conclude that the type of electoral systems does not affect economic performance but parliamentary government is associated with growth-promoting policies, such as open trade and property protection rights. ${ }^{60}$ By contrast, Knutsen reports that proportional and semi-proportional electoral rules do produce substantially higher annual per capita growth rates compared with plural-majoritarian rules. ${ }^{61}$

If types of institutional arrangements affect prosperity, however, the exact reasons behind any observed regularities still need to be established. One argument emphasizes that parliamentary executives and majoritarian elections commonly produce single-party governments, where management of the economy rests in the hands of the leader of the governing party. ${ }^{62}$ This process has certain advantages for establishing a clear chain of electoral accountability, where the team of cabinet ministers for the governing party is collectively responsible for economic performance, while individual representatives of the governing party are also accountable to local single-member constituencies. This arrangement facilitates public evaluations ('the buck stops here') and thus retrospective economic voting at the ballot box. Similarly, unitary and centralized states also strengthen the direct chain of electoral accountability. ${ }^{63}$ By contrast, electoral accountability is weakened in presidential and mixed executives, in proportional electoral systems which usually generate coalition governments, and in federal states. Where party control is divided among the major branches of the legislature and executive it becomes more difficult for citizens to attribute clear praise or blame for management of economic performance. ${ }^{64}$ The attribution of responsibility is further reduced under conditions of multi-level governance and economic globalization; problems with the American sub-prime mortgage triggered the banking crisis in 2008, so who should citizens in Greece, Ireland, and Iceland blame for their economic woes: their own leaders, or those in the United States, or indeed the actions of the major multinational financial 
corporations and international agencies? According to this view, power-concentrating constitutional arrangements (with plurality or majoritarian electoral systems, parliamentary executives, and unitary states) should produce the clearest chain of responsibility and the strongest electoral incentives for governing parties to manage the economy competently and well.

At the same time, however, an alternative line of reasoning suggests that power-sharing democracies may promote greater macroeconomic policy stability. Lijphart suggests that under these arrangements, decision-making require greater compromise establishing agreement among the multiple coalition parties in government. ${ }^{65}$ This is predicted to generate greater stability, moderation, and continuity in medium and long-term macro-economic policy, which, in turn, is expected to expand business confidence, reduce investment risks, and improve prosperity. ${ }^{66}$ By contrast, majoritarian democracies with single-party governments are thought more vulnerable to abrupt policy reversals following major shifts in party fortunes. Under these arrangements, such as historically in the UK and Australia, sudden 'stop-go' reversals in macroeconomic policies are possible when the major parties on the left and right rotate in government office, such as switches in fiscal policy and public spending, trade union bargaining rights, or economic deregulation. Abrupt macro-economic policy reversals and instability are thought to be problematic for investors, creating uncertainty and thereby heightening risk.

Thus there are several plausible reasons why power-sharing institutions may matter for growth, but debate continues about the underlying mechanism and the predicted effects. Theories identify rival pathways but it is not clear whether electoral accountability or political stability is more important for income. If democratic effects on growth are conditional, then growth should be observed to vary by the type of institutional arrangements (including whether states are federal or unified, whether electoral systems are proportional or not proportional, and whether the type of executive is parliamentary or not). Nevertheless the state of knowledge about these relationships does not allow us to predict the direction of any effects with any degree of confidence. Moreover the complexity of alternative constitutional arrangements and diverse channels of electoral accountability means that coding institutions into proxy dichotomous categories loses much find-grained detail about how institutions work in practice.

\section{Equilibrium theory and democratic governance}

Lastly in counter-balance to all these claims, the equilibrium argument suggests that previous claims need to be synthesized into a unified theory where the combination of both liberal democracy and governance capacity is understood as contributing towards economic growth. ${ }^{67}$ In particular, electoral accountability increases the pressures on governments to deliver an effective performance, but public officials can only do so if the state has the technical capacity and skills to manage macroeconomic policies. If government leaders are thrown out of office for failing to improve the economy, but opposition parties are similarly unable to reduce levels of inflation and unemployment, then the result are likely to deepen disillusionment with the political process. ${ }^{68}$ If economic problems continue over successive administrations, then disenchantment may spread so that the public comes to lack confidence in the regime, and ultimately, faith in democratic ideals and principles. On the other hand, if state officials are competent and effective at managing economic growth, expanding the country's GDP, but government leaders 
are not responsive and accountable to citizens, then there is no mechanism which makes sure that wealth trickles down to benefit the living standards of the general public rather than the Swiss bank accounts of economic elites. For these reasons, equilibrium thesis suggests that the combination of liberal democracy and governance capacity will prove the most effective recipe for growth.

\section{II: The research design}

The previous body of research therefore suggests several propositions which can be tested in this study. The empirical evidence needs to be reexamined cautiously, however, due to the series of technical challenges facing any systematic study of this relationship. This includes issues of reciprocal causality, omitted variable bias, invalid conceptualization, measurement errors, and bias arising from missing data.

First, major difficulties arise from complex issues of reciprocal causality; regimes may facilitate growth. But economic development is also widely believed to provide conditions conducive both to processes of democratization and to strengthening investment in the quality of governance. ${ }^{69}$ A large body of economic and sociological research has observed that wealthy societies have usually been more democratic. The political sociologist Seymour Martin Lipset laid the groundwork for this perspective, specifying that: "The more well-to-do a nation, the greater the chances that it will sustain democracy." 70 Greater affluence consolidates democracy, Lipset theorized, by expanding levels of human capital (literacy, schooling), widening media access, broadening the middle classes, dampening the effects of extreme poverty, facilitating intermediary civil society organizations, such as labor unions and professional associations, and promoting the cultural values of democratic legitimacy and social tolerance. ${ }^{71}$ Acemoglu, Johnson and Robinson argue that in the short-term the direction of causality runs from development to governance, rather than the reverse, controlling for country fixed-effects, although they acknowledge that in the longterm (over the last 500 years) there is a positive correlation between economic development and processes of democratization. ${ }^{72}$ To mitigate the effects of reversed causation, the measures for the independent variables are taken for the year before the annual measure of economic growth. I also include measures of levels of economic development from previous years; this makes sense if growth is understood as a sticky phenomenon which is not invented anew every year. Past growth can be expected to strengthen future growth. The measure of income also helps to capture all the accumulated factors which have expanded growth until the current observation and which are unobserved in the models.

In parsimonious but under-specified models, omitted variable bias may also prove problematic; another independent variable, not included in controls, may determine simultaneously both the type of regime and levels of economic growth. For example, developing societies meeting international standards of good governance and democracy are more likely to attract international aid as well as international private-sector investment. ${ }^{73}$ As a result, states with well-governed democracies may experience faster growth than those with autocratic regimes, but this should not be attributed directly to how different types of regimes manage their economies. Many studies of economic growth analyze the importance of institutions, trade and geography, but fail to control for social structural factors, such as levels of ethnic fractionalization or income inequality, as well as the potential role of civil wars and inter-state conflict, all of which can be expected to depress growth. Econometric studies of democracy also commonly fail to distinguish the role of power-sharing and 
power-concentrating democratic institutions, which can be expected to differ in their economic effects. ${ }^{74}$ Many parsimonious economic models are elegant but underspecified. To guard against this tendency, by contrast this study uses a battery of items to control for several sets of factors: constitutional arrangements, prior economic conditions, geography, social structure, cultural traditions, and global trends (see Table 5.1). Moreover, many models examine the impact of either democracy or governance, but not the interaction of both phenomena.

Thirdly, other difficulties arise from poor conceptualization and measurement errors; a growing consensus has arisen today about standard indicators of liberal democracy, using the Gastil Index from Freedom House and the Polity IV democracy-autocracy scale. ${ }^{75}$ Notions of 'good governance' still remain vague and poorly defined, however, and the available empirical indicators may well be invalid measures of the overarching concepts. ${ }^{76}$ The World Bank Institute good governance indices are widely employed, in both theoretical and applied policy research but they have been criticized as suffering from problems of perceptual biases, adverse selection in sampling, and conceptual conflation with economic policy choices. ${ }^{77}$ For example, the WBI indices include 'regulatory quality' based on the assumption that minimal intervention is optimal, yet this conflates specific controversial policy prescriptions with the quality of governance. Many of the indices are actually outcome measures of good governance, rather than 'input' or process measures; for example control of corruption is widely recognized as important for growth, but estimates arising from broad and abstract measures do not tell us anything about what government procedures, institutions or policies actually work to minimize corruption. There are potential problems arising from all perceptual measures of governance performance, especially those based on unrepresented groups of elites such as business-people, academics, and journalists, since favorable outcomes (such as conditions of economic growth) can color evaluations of the quality of governance. This can prove particularly problematic with the analysis of cross-national data, since growth rates may be spuriously correlated with perceptions of good governance. Longitudinal analysis is needed but the WBI indices only started to be estimated in 1996. Many studies have also emphasized the importance of 'rule of law' for development, but this abstract and vague idea contains multiple components. ${ }^{78}$ If 'rule of law' matters, it is still unclear whether policymakers heeding these lessons should seek to strengthen the independence of the courts and judiciary, develop procedures and institutions designed to control corruption, expand professional training and capacity building for lawyers, prioritize police protection of person and property, expand access to transitional justice, or engage in the demilitarization of security forces, or 'all of the above'. The underlying institutional mechanisms, and the policy implications arising from the governance research literature, thus remain under-specified and poorly understood. To overcome problems of measurement error, this study tests the robustness of key relationships using alternative measures of liberal democracy and bureaucratic governance.

Lastly, potential problems of systematic bias arise from missing data in the longitudinal and cross-national analysis of development indices. Moreover the missing data is often not randomly distributed; instead it is most common in poorer nations, in societies deeply-divided by conflict, and in patronage autocracies. In these contexts, national statistical offices often lack the resources, technical capacity, or political-independence to gather reliable internationally-standardized statistics from official statistics, regular household surveys, or census data, even for basic indices 
monitoring progress for the MDGs. Unfortunately other systematic biases can also arise from standard social science datasets; for example, one of the standard indicators of democracy is provided by the Polity IV series classifying regimes since 1800 , but this dataset excludes all micro-states around the world (with populations below 500,000). Polity IV covers 164 independent nation-states worldwide, with the biases already noted arising from the exclusion of micro-states. International statistics also rarely monitor data from dependent territories, such as Montenegro, Kosovo, and Timor-Leste, so that time-series data of past trends is lacking when these societies gain independent statehood. Consequently major problems can arise from the limited country coverage included in cross-national and time-series comparisons, since the independent nation-states included in the analysis are not a random sample of all countries in the world. Many of the governance indices are also relatively recent in origin, covering the period since the mid-1980s (ICRG) or since the mid-1990s (WBI), hence long-term processes are difficult to determine. To mitigate problems arising from systematic bias, this study compares the robustness of the results using alternative indices with different country coverage.

To examine the evidence, this study uses a mixed research strategy. First we can examine the descriptive statistics to observe the general patterns. The regime classification is based on the Freedom House liberal democracy index and the ICRG bureaucratic governance index which are both standardized to 100 point scales and dichotomized around the mean to create a four-fold typology. This distinguishes regimes which are bureaucratic democracies, bureaucratic autocracies, patronage democracies and patronage democracies. ${ }^{79}$ Multivariate models can then analyze cross-national time-series panel data for countries worldwide, to determine the predicted impact of liberal democracy and bureaucratic governance indices upon changes in economic growth, incorporating a wide range of controls. Change in per capita GDP is measured in purchasing power parity, derived here from the chain series provided by the Penn World Tables. ${ }^{80}$ Models examine the effects of the Freedom House Gastil index of democracy, providing the most comprehensive country coverage of all independent nation-states. The quality of Bureaucratic Governance is gauged using the ICRG annual estimates which are available for a more restricted range of 134 countries since 1984. Both these indices are standardized to 100-point scales, for comparability and ease of interpreting the results. To monitor conditional effects arising from particular types of powersharing constitutions, the models also classify whether countries are federal or unitary states, whether the electoral system used for the lower house of the national parliament is proportional representation or not, and the type of presidential or parliamentary executive. ${ }^{81}$ A series of comprehensive controls (see Table 5.1) are introduced for the effects on growth arising from economic factors, geographic characteristics, social structural variables, cultural traditions, and global trends. The panel models employ ordinary least squares (OLS) regression with panel corrected errors, to correct the problem of serial correlation arising from repeated observations of the same countries over time. Robustness checks replicate the models to compare the results using the alternative Polity IV scale of democracy-autocracy.

\section{The effects of regimes on growth}

First, does growth vary systematically by the type of regime? To look initially at the descriptive data, Figure 5.1 compares mean levels of annual economic growth during the whole period under review (from 1984 to 2007) for each type of regime, without any prior controls. The results confirm that bureaucratic democracies experienced 
the bighest annual rates of per capita growth (2.49\%), as well as the most stable growth rates $(\mathrm{StDev}=3.92)$. Equilibrium theory predicts that bureaucratic democracies combine the most effective macro-economic management by the state, with competent and technically-skilled officials steering the economy in the main financial ministries, combined with the accountability which democratic governments face for their performance to the electorate. The initial comparison provides some preliminary support for the claim that this type of regime provides the underlying conditions most conducive for stable and sustained growth. As illustrated in Figure 5.2, trends in the mean growth rate among bureaucratic democracies is relatively steady, providing predictable conditions which are expected to encourage investor confidence, without showing the sharp fluctuations and volatility found among other types of regimes.

[Figures 5.1 and 5.2 about here]

By contrast, as also predicted by equilibrium theory, compared with all other types of regimes, patronage autocracies usually perform most poorly, displaying mean annual growth of only $1.23 \%$ during these years, half the rate of growth experienced by bureaucratic democracies. Patronage autocracies also display the sharpest peaks and troughs in their growth rate trends (St. Dev. $=9.88$ ); these types of regimes typically occasionally perform very well - or very badly (see Figure 5.2). Thus in the late-1980s and the early 1990s, the global recession depressed all economies. The United States saw soaring unemployment, massive government budgetary deficits, and a slowdown in GDP. But while this downturn almost wiped out growth in bureaucratic democracies, patronage autocracies dipped sharply into deeply negative territory. In particular, oil-dependent autocracies are prone to experience sharp swings in GDP following large fluctuations in the price of energy, such as the volatility evident in Equatorial Guinea, Saddam's Iraq, and Kuwait. Several states transitioning from autocracy and emerging from conflict have also experienced a substantial short-term surge in growth under newly-elected regimes, such as Liberia in 1997 and Afghanistan in 2002. Investment in infrastructure and economic recovery, funded partially by international recovery and reconstruction assistance, generates a sudden spike, but long-term growth in these circumstances often proves unsustainable. By comparison, both patronage democracies and bureaucratic autocracies fall roughly mid-way between the other regime categories, with mean growth rates of 1.93 and 1.81 percent respectively, as well as proving middling in their overall level of growth volatility (see Figure 5.2).

An alternative way to examine the descriptive evidence is to compare rates of growth for states which do not experience any sustained regime change during the period under comparison. Thus we can compare cases classified as stable regimes, defined as those which fall into the same regime category in both 1984 and 2007; hence Angola, Cameroon, Libya, Syria, Togo and Zimbabwe, for example, are classified as stable patronage autocracies; Sri Lanka, Bolivia and Senegal represent stable patronage democracies; Saudi Arabia, Brunei, Bahrain and China exemplify stable bureaucratic autocracies; and lastly stable bureaucratic democracies during this period include states such as Australia, France, Turkey, and Trinidad and Tobago.

[Figure 5.3 about here]

Figure 5.3 illustrates the contrasts in income levels and growth rate experienced among each of these types of regimes. In 1984, stable bureaucratic democracies start with the high average levels of per capita GDP $(\$ 17,342)$, and during these decades these states also see average incomes rise by two thirds, the 
largest amount of any category, to reach \$29,238 per capita in 2007. In 1984 bureaucratic autocracies were initially even more affluent, with average incomes of $\$ 31,885$. But far from becoming more prosperous, citizens living under these regimes experienced falling living standards during these years, to reach $\$ 26,223$ per capita. Patronage democracies start with the lowest average income level of any regime type in 1984 (\$3,901) and their average income levels rise slightly although still to only $\$ 5,597$. Lastly patronage autocracies were also poor societies in 1984 , with per capita incomes of only $\$ 5,232$, and their average income levels fall slightly during recent decades. Thus bureaucratic democracies accelerate their lead over all other types of regimes, especially widening the disparities with patronage democracies. In 1984, bureaucratic democracies enjoyed average income levels just over three times the level of patronage autocracies. By 2007, the equivalent gap had grown to roughly six times the level.

But growth is widely recognized to be the product of many factors beyond regime institutions. And in a reciprocal relationship, growing affluence is believed to strengthen the quality of democratic governance. Thus these findings should not imply be taken to imply that the type of regime necessarily causes growth, due to the need for many other controls in multivariate models and the need to address complex issues of endogeneity when interpreting this relationship. Rising incomes have been regarded as a cause of both growing democratization (through the expansion of the middle classes, the Lipset thesis), as well as better governance (through the resources invested in the bureaucracy and public demands for services). ${ }^{82}$ For example, both the United States and Mediterranean European countries have been forced to cut public services and shrink the size of the public sector workforce employed at local and national levels after experiencing an economic downturn, triggered by the 2008 housing crisis in America, global financial pressures, reduced revenues, and growing government budgetary deficits. Thus the recession has had a direct impact on governance, by constraining the provision of basic public services, such as schools, roads and health care.

[Table 5.1 about here]

The simple correlations and the multivariate models presented in Tables 5.1 and 5.2 examine the core propositions arising from theories about the effects of democratic governance controlling for many factors which the literature suggests contribute towards prosperity, including geographic variables, prior economic conditions, social structural factors, cultural traditions and global trends. The simple correlations suggest that multiple factors are significantly associated with growth, including many structural conditions which are largely fixed or slowly changing. Thus the geographic location of any country (measured by latitude) is strongly correlated with rates of economic growth; since location is fixed, this suggests that geography helps determine income. Similarly countries which are predominately Muslim societies have negative growth rates, suggesting that religious traditions affect the economy. The levels of liberal democracy $\left(\mathrm{R}=.038^{* * *}\right)$ and bureaucratic governance $\left(\mathrm{R}=.083^{* * *}\right)$ are also weakly correlated with growth, although here it is not possible to determine the direction of causation in the relationship due to the possibility of reciprocal effects and omitted variable bias. The multivariate regression models lag all the independent variables by one year, as a partial control on endogeneity. The regression models present the unstandardized beta regression coefficients, their significance, and the panel corrected standard errors, along with the number of observations and countries under comparison. 
If we first examine the effects of the controls, factors which are consistently positive and significantly related to growth across all models include the location of countries (measured in latitude or degrees distant from the equator), trade flows, and countries with the legacy of a British colonial background. Latitude is a proxy for many other factors affecting the tropics, from climate and agriculture (the availability of potential crops and animals) to the prevalence of disease. ${ }^{83}$ Trade is important for growth via closer integration into global markets for exchanging products, services, and commodities. Negative factors significantly depressing income across many (not all) models include levels of internal conflict; societies experiencing civil wars, domestic violence, and instability can be expected to have conditions deterring investment, while conflict also destroys essential infrastructure and physical capital, increases military expenditure, and reduces the total number of people potentially employed in the civilian labor force. In terms of social heterogeneity, linguistic fractionalization is consistently negatively related to growth. Religious fractionalization also often proves negative but the coefficient is insignificant. Easterly and Levine have highlighted the important role of ethnic fractionalization in explaining lack of growth in Sub-Saharan Africa, although the type of ethnic identity and social cleavage appears important for its effects. ${ }^{84}$ The role of natural resources could potentially function as a blessing (by funding investment) or a curse (by encouraging corruption and inequality). ${ }^{85}$ The results in these models confirm the latter interpretation; an extensive literature suggests that income arising from oil and gas natural resources is often captured by predatory elites, as well as being a cause for conflict and instability. Lastly, contra the assumption that human capital contributes towards growth, and in line with Easterly's skeptical view, ${ }^{86}$ secondary school attainment was not consistently and significantly linked to prosperity.

\section{Democratic governance and growth}

After controlling for these factors, what is the impact of governance? Models in Table 5.1 test the main effects suggested by theories of good governance. The results demonstrate that after applying the controls, in Model 1a economic growth is not significantly affected by neo-liberal measures of good governance (including the World Bank Institute's estimates of rule of law, property rights and control of corruption), nor in Model 1b by bureaucratic governance alone (as monitored by the ICRG). These results are contrary to those presented by Evans and Rausch, but their analysis of Weberian governance was restricted to three dozen developing countries. ${ }^{87}$ When both liberal democracy and bureaucratic governance are entered into model $1 \mathrm{c}$, however, both emerge as significant predictors of economic growth. Equilibrium theory posits that it is important to counterbalance the accountability of elected officials for the country's economic performance with the capacity of the public sector to manage the economy effectively, and the results lend support to this argument. This model shows that both these factors have effects which are similar in strength; an improvement of $10 \%$ in the 100-point scales of liberal democracy and bureaucratic governance increases annual per capita growth in GDP by roughly 0.2 or $0.3 \%$ higher respectively. This may appear to be a relatively modest impact in itself, but since average growth rates for all countries throughout these years is $1.9 \%$, the rise is not inconsiderable.

[Table 5.1 and 5.2 about here]

A similar series of models in table 5.2 examine the impact of democracy upon economic growth, based on the alternative arguments considered earlier. The 
results in Model 2a demonstrate that after applying the same range of controls, liberal democracy, by itself, has no direct impact on growth. A robustness check, replicating the models but substituting the Polity IV standardized democracy scale, produced a similar result. These results are contrary to the conclusion of Halperin et al, based on comparing the economic performance of least developed nations but failing to control for many factors driving both democratization and growth. ${ }^{88}$ At the same time, the results provide further confirmation for the findings reported in many previous studies which are skeptical about the link between democracy and growth, including studies published by Barro, Przeworski et al, and Doucouliagos and Ulubasoglu. ${ }^{89}$ There are many reasons why the assumed mechanism of electoral accountability may fail, so that governments may be returned to office, despite a poor economic performance, or they may be kicked out despite growing prosperity. In liberal democracies, the chains of accountability linking citizens with representatives are complex. In systems with divided government and power-sharing arrangements, it is difficult to assign praise or blame for macroeconomic management. Government survival during inter-electoral periods depends upon parliamentary support, as well as popular votes. Voters can cast their ballots based on many reasons unconnected with past or future economic performance. The general public may find it difficult, or even impossible, to evaluate more technical and abstract economic conditions (such as the size of the government deficit, the level of any trade imbalance, or the international strength of the currency), still less to attribute praise or blame for these conditions. Citizens' evaluations of many aspects of economic performance, where they lack direct pocket-book experience, are framed by the news media. Parties are accountable to members and partisan supporters, as well as the general public. 90 Given the complexity of assigning responsibility for economic management in longestablished democracies, where parties and leaders have established a long-track record over successive administrations, it is not surprising if this accountability proves even weaker in many countries where parties and leaders have not yet established a strong reputation which could form a rational basis for retrospective economic voting. Moreover even if the chain of accountability works perfectly, so that politicians are accountable for their handling of the economy, and they have every intention of serving the public interest, this does not mean, by any means, that they can necessarily deliver on their economic promises if states lack the technical capacity to do so.

Model $2 \mathrm{~b}$ examines the impact of several of the core institutions associated with power-sharing arrangements. If institutional effects on growth are conditional, then growth is expected to vary according to whether states are federal or unified, whether electoral systems are proportional or majoritarian, and whether the type of executive is parliamentary or presidential, although the direction of any institutional effects is not easy to predict from existing theories. Model $2 b$ in Table 5.2 demonstrates complex results after applying all the prior controls. In particular, the comparison of parliamentary executives in all the countries under comparison shows a strong and significant impact on growth, as Persson and Tabellini have reported. ${ }^{91}$ Countries with either mixed executives (combining a presidency and prime minister) or with a pure presidential executive generally have lower prosperity than parliamentary systems. Overall these general findings serve to support the argument that parliamentary executives usually strengthen collective accountability; in these systems, where responsibility for managing the economy rests with the party or parties in government, it is easier for electors to assess economic performance and to 'kick rascals out of office'. By contrast, in regimes with mixed or presidential 
executives, when given the opportunity to choose leaders at the ballot box, it is more difficult for citizens to assign clear-cut praise or blame for economic conditions. Similarly the direct effects of proportional representation electoral systems are also significantly related to income, further confirming Knutsen's conclusions. ${ }^{92}$ By contrast, federalism does not appear to have a direct effect on economic performance. Yet the exact reasons for these patterns are not apparent theoretically, since power-sharing theories predict interaction effects, emphasizing the role of democratic institutions. Contrary to the direction predicted by consociational arguments, in fact the interaction effect between liberal democracy and parliamentary executives proved weakly negative. The other interaction effects from institutions in power-sharing democracies were insignificant.

Lastly, model 2c in Table 5.2 tests the argument that democracy has an indirect effect on growth since this type of regime typically makes a greater investment in human capital than autocracies. Human capital has many dimensions and it is measured here by gross enrollment (male and female) in secondary schooling. The interaction effect of democracy and human capital on growth emerges as significant but negative, in the contrary direction to that predicted theoretically. There are reasons to be skeptical about the assumed importance of human capital for growth, for instance William Easterly suggests that the dramatic expansion in schooling and literacy experienced in many developing countries during the last four decades have, in fact, proved distinctly disappointing for raising incomes. ${ }^{93}$ Creating skills in the workforce is insufficient for prosperity, he argues, if societies continue to lack access to new technologies, or if there are few job openings for skilled workers and high levels of long-term unemployment. Moreover growth may come through alternative strategies; hence Przeworski et al found that democratic and autocratic regimes achieved prosperity through different routes. The study confirmed that among wealthier nations, democracies were more likely to invest in human capital (including education and training). But this did not necessarily generate a better economic performance, since wealthier autocracies achieve equivalent gains in productivity and growth through the alternative mechanism of higher fertility rates, which expanded the overall size of their workforce population.

\section{IV: Conclusions and Implications}

The varied thinkers subscribing to an 'idealist' viewpoint commonly make two core claims favoring democratic governance. Firstly, idealists argue on normative grounds that legitimate governance is based on the will of the people, as expressed through the institutions of liberal democracy. These claims are embodied in international conventions, agreed by the world's governments, notably Article 21 of the 1948 Universal Declaration of Human Rights: "The will of the people shall be the basis of the authority of government; this will shall be expressed in periodic and genuine elections which shall be by universal and equal suffrage and shall be held by secret vote or by equivalent free voting procedures." Human rights-based arguments reflect universal claims. Rights-based arguments reflect powerful moral arguments which resonate widely among those sharing democratic values. Realists also suggest that 'good' governance is intrinsically valuable; in this view, states should reflect the principles of clean, efficient, and effective public administration, rule of law, and impartial decision-making. Confronted by those who remain skeptical about these claims, however, the second strand of the idealist and realist arguments suggest that democratic governance is not only of intrinsic value, but this type of regime also has instrumental benefits. The way that leaders are chosen and held accountable by citizens, idealists believe, has 
important consequences for whether they act in the public interest. Similarly states which are more competent, effective and efficient when steering the economy are more likely to produce stable growth and security, acting as partners for achieving developmental goals in conjunction with the international community.

The evidence which help to determine institutional effects is complex to analyze, not least due to problems of missing data, reciprocal causation, limited country coverage, and the challenges of conceptual validity for many common indices. This study has sought to throw fresh light on these issues, building upon the argument that neither liberal democracy nor good governance, in isolation, can be expected to generate conditions for sustained growth, although the combination of these characteristics is predicted to prove important for prosperity. The result of the analysis lends confirmation to this argument, while also casting serious doubt on several alternative theories. The equilibrium thesis emphasizes that both liberal democracy and governance capacity need to be strengthened simultaneously for effective development, within the constraints posed by structural conditions. Democracy and governance are separate phenomena but their combination is necessary (although not sufficient) to achieve progress. Liberal democracy is theorized as critical for development, by allowing citizens to express their demands, to hold public officials to account, and to rid themselves of incompetent, corrupt or ineffective leaders. Yet rising public demands which elected officials cannot meet is a recipe for frustration - or worse. In this sense, the issue is not simply about providing electoral incentives so that vote-seeking politicians pay attention to social needs but also providing elected leaders with the capacity to implement effective policies. Thus the quality of governance is also predicted to play a vital role in development, where the notion of 'good governance' is understood in terms of expanding the capacity of elected representatives and officials to manage the delivery of basic public goods and services, so that leaders can respond effectively to citizen's demands. Nevertheless the quality of both democracy and governance are not isolated phenomena; regimes reflect, as well as shape, the enduring structural conditions in each society. The international development community, national governments, and civil society organizations have devoted growing resources to strengthening democracy and governance. The difficult and complex challenge facing reformers is therefore to develop simultaneously both the institutions of liberal democracy and good governance, within the structural constraints of each society, rather than prioritizing one or the other of these twin development goals. 
Figure 5.1: Annual growth in income by type of regime

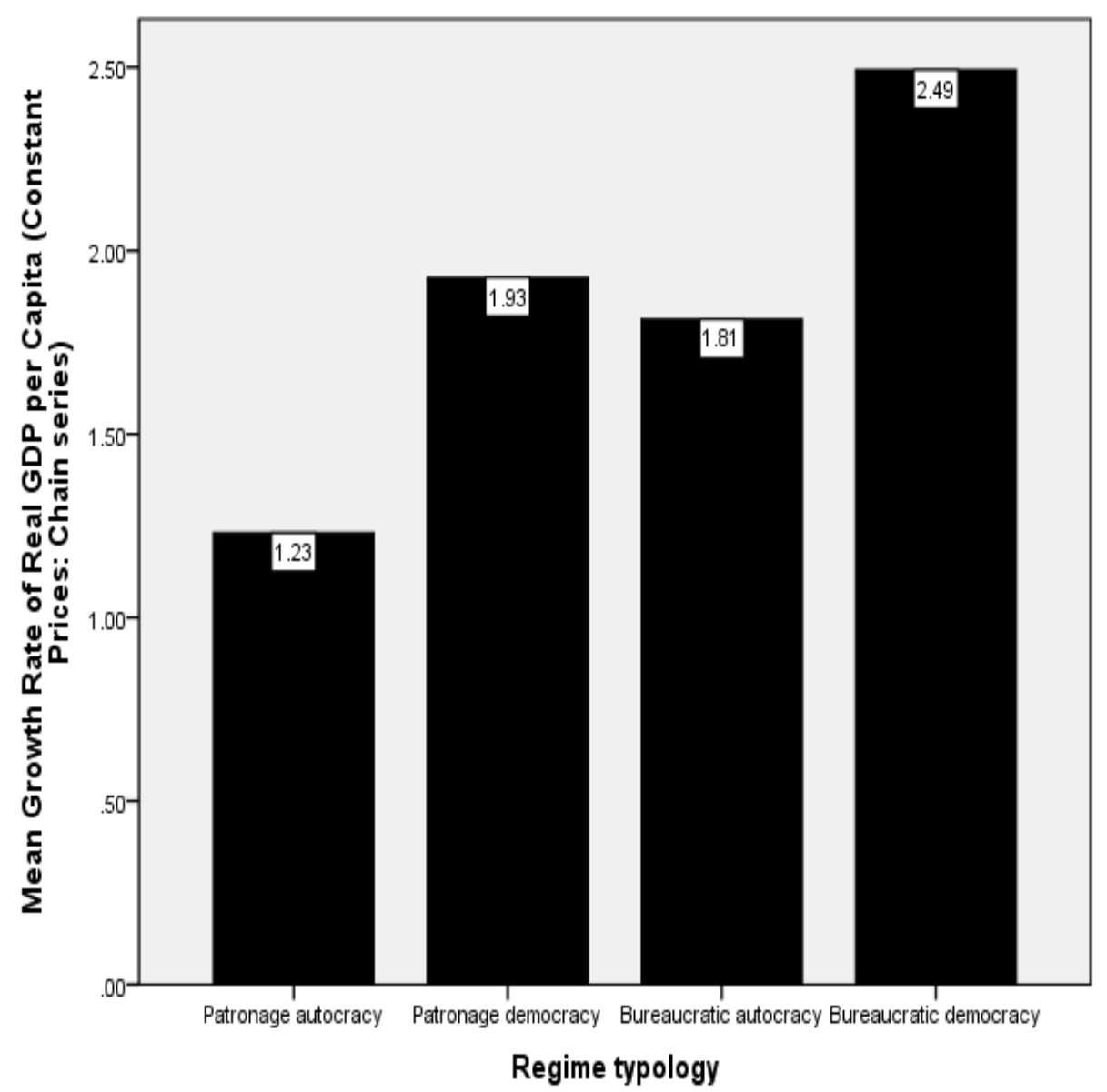

Note: Mean annual growth of income per capita in purchasing power parity from the chain series index of the Penn World Tables, 1984-2007. For the regime typology, see Appendix A. 
Figure 5.2: Mean rate of growth 1980-2010 by type of regime
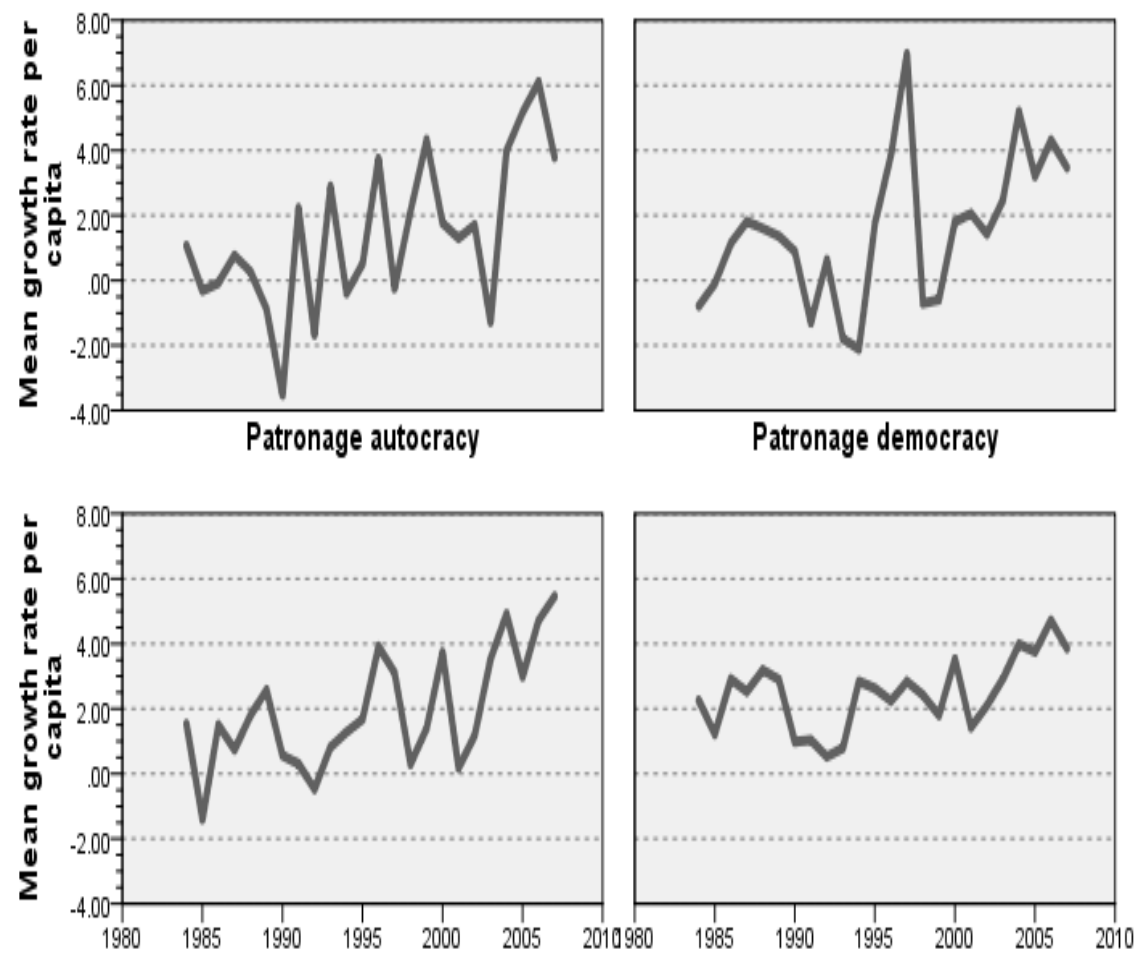

Bureaucratic autocracy

Bureaucratic democracy

Note: Mean annual growth of income per capita in purchasing power parity (constant prices) from the chain series index of the Penn World Tables, 1980-2010. For the regime typology, see Appendix A. 
Figure 5.3: Growth by type of regime

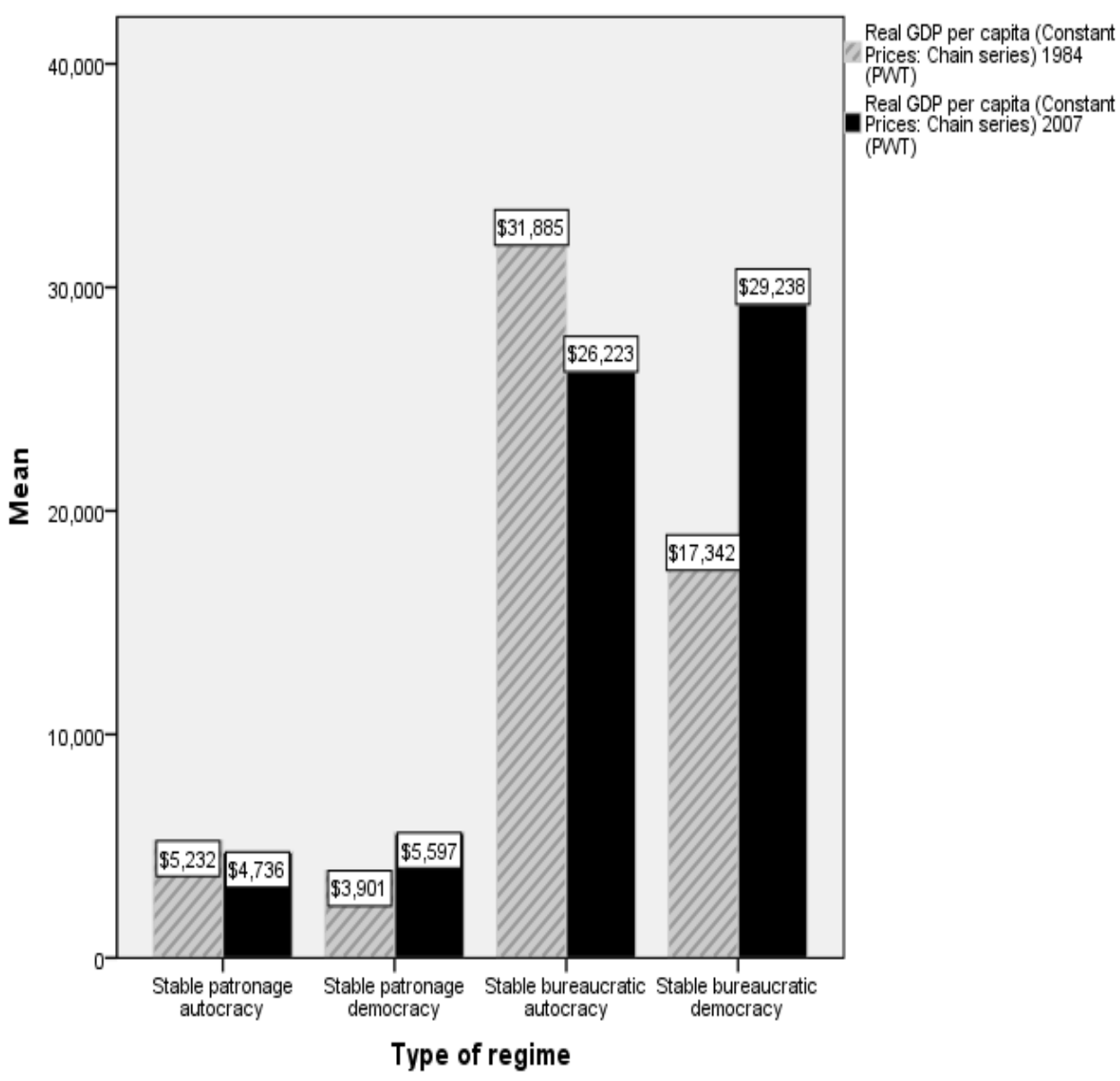

Note: Mean annual growth of income per capita in purchasing power parity from the chain series index of the Penn World Tables, 1984-2007. For the regime typology, see Appendix A. 
Table 5.1: The impact of governance upon economic growth

\begin{tabular}{|c|c|c|c|c|c|c|c|c|c|c|c|}
\hline \multirow[t]{3}{*}{ Models } & & & \multicolumn{3}{|c|}{$1 \mathrm{a}$} & \multicolumn{3}{|c|}{$1 b$} & \multicolumn{3}{|c|}{ 1c } \\
\hline & \multicolumn{2}{|c|}{$\begin{array}{c}\text { Economic growth } \\
\text { correlations }\end{array}$} & \multicolumn{3}{|c|}{$\begin{array}{l}\text { Good governance } \\
\text { institutions }\end{array}$} & \multicolumn{3}{|c|}{$\begin{array}{c}\text { Bureaucratic } \\
\text { governance }\end{array}$} & \multicolumn{3}{|c|}{$\begin{array}{l}\text { Democratic } \\
\text { governance }\end{array}$} \\
\hline & $\mathbf{R}$ & $\mathrm{p}$ & b & $\mathrm{p}$ & PCSE & b & $\mathrm{p}$ & PCSE & b & $\mathrm{p}$ & PCSE \\
\hline \multicolumn{12}{|l|}{ " REGIME EFFECTS } \\
\hline Liberal democracy $(\mathrm{FH})$ & .038 & $* * *$ & & & & & & & .023 & $*$ & .014 \\
\hline Bureaucratic governance (ICRG) & .083 & $* * *$ & & & & -.003 & & .007 & .032 & $*$ & .016 \\
\hline $\begin{array}{l}\text { Good governance (Rule of law, property } \\
\text { rights and control of corruption) }\end{array}$ & -.026 & & -.188 & & .143 & & & & & & \\
\hline \multicolumn{12}{|l|}{ CONTROLS } \\
\hline \multicolumn{12}{|l|}{ Economic } \\
\hline Trade flows & .092 & $* * *$ & .032 & $*$ & .014 & .029 & $* * *$ & .006 & .029 & $\begin{array}{l}* * \\
*\end{array}$ & .006 \\
\hline Income (Per capita GDP) & .040 & $* * *$ & .001 & & .000 & .001 & & .000 & & & .000 \\
\hline \multicolumn{12}{|l|}{ Geographic } \\
\hline Location (Latitude) & .063 & $* * *$ & 6.75 & $\begin{array}{l}* \\
* \\
*\end{array}$ & .642 & 2.36 & ** & .633 & 3.13 & $\begin{array}{l}* * \\
*\end{array}$ & .798 \\
\hline Area size $(\mathrm{Sq} . \mathrm{Km})$ & -.018 & & -.001 & & .000 & .001 & & .000 & -.001 & & .000 \\
\hline Natural resources (Oil/gas rents) & .008 & & -.001 & & .000 & .001 & & .000 & -.001 & & .000 \\
\hline \multicolumn{12}{|l|}{ Social Structure } \\
\hline Linguistic fractionalization & -.039 & $* * *$ & -.244 & & .854 & -.575 & * & .203 & -.259 & & .227 \\
\hline Religious fractionalization & .000 & & .681 & & .793 & -.125 & & .424 & -.026 & & .427 \\
\hline Human capital (secondary schooling) & .053 & $* * *$ & .001 & & .011 & -.008 & & .005 & -.005 & & .005 \\
\hline Logged population size & -.005 & & .247 & & .380 & .714 & $* * *$ & .149 & .672 & & .147 \\
\hline Internal conflict & -.058 & *** & .238 & & .453 & -.104 & & .242 & -.077 & & .249 \\
\hline \multicolumn{12}{|l|}{ Cultural traditions } \\
\hline Muslim society & -.038 & $* * *$ & 1.45 & $*$ & .779 & .282 & & .461 & .319 & & .434 \\
\hline British colonial legacy & -.012 & & .959 & $*$ & .290 & .611 & $* * *$ & .130 & .580 & $* *$ & .129 \\
\hline \multicolumn{12}{|l|}{ Global trends } \\
\hline Year & .042 & $* * *$ & -.094 & & .105 & -.004 & & .030 & -.009 & & .031 \\
\hline R-2 & & & & .085 & & & .030 & & & .030 & \\
\hline Number of observations & 5767 & & & 508 & & & 1769 & & & 1769 & \\
\hline Number of countries & & & & 103 & & & 95 & & & 95 & \\
\hline Years & 20 & & & 5 & & & 20 & & & 20 & \\
\hline
\end{tabular}

Note: The models present the unstandardized beta coefficients and the statistical significance of Ordinary Least Squares linear regression models with Panel Corrected Standard Errors. The dependent variable is income per capita in purchasing power parity from the chain series index of the Penn World Tables. ${ }^{* *} \mathrm{p}<0.001,{ }^{* *} \mathrm{p}<0.001,{ }^{*} \mathrm{p}<0.05$. For details of all the variables, see the technical appendix. 
Table 5.2: The impact of democracy upon economic growth

\begin{tabular}{|c|c|c|c|c|c|c|c|c|c|}
\hline Model & & $2 a$ & & & $2 b$ & & & $2 \mathrm{c}$ & \\
\hline & Liber & 1 Dem & cracy & & $\begin{array}{l}\text { ver-sha } \\
\text { stituti }\end{array}$ & & & $\begin{array}{l}\operatorname{mocrac} \\
\operatorname{man} \mathrm{C}\end{array}$ & \\
\hline & b & $\mathrm{p}$ & PCSE & b & $\mathrm{p}$ & PCSE & b & $\mathrm{p}$ & PCSE \\
\hline REGIME EFFECTS & & & & & & & & & \\
\hline Liberal democracy $(\mathrm{FH})$ & -.004 & & .003 & .017 & $* *$ & .005 & .016 & $*$ & .007 \\
\hline Liberal democracy $*$ human capital & & & & & & & -.001 & $* * *$ & .000 \\
\hline Federal state (1) Unitary (0) & & & & -.543 & & .587 & & & \\
\hline PR electoral systems (1)/ Majoritarian or mixed & & & & 1.73 & $* * *$ & .007 & & & \\
\hline Parliamentary Executive (1)/ Other (0) & & & & 4.69 & $* * *$ & 1.36 & & & \\
\hline Liberal democracy $*$ federal state & & & & -.014 & & .007 & & & \\
\hline Liberal democracy $*$ PR electoral system & & & & -.014 & & .006 & & & \\
\hline Liberal democracy * Parliamentary Executive & & & & -.022 & $* * *$ & .013 & & & \\
\hline CONTROLS & & & & & & & & & \\
\hline Economic & & & & & & & & & \\
\hline Trade flows & .032 & $* * *$ & .004 & .030 & $* * *$ & .004 & .030 & $* * *$ & .004 \\
\hline Income (Per capita GDP) & .001 & & .000 & .001 & * & .000 & .001 & $*$ & .000 \\
\hline Geographic & & & & & & & & & \\
\hline Location (Latitude) & 1.99 & $* *$ & .527 & 1.78 & * & .567 & 2.14 & $* * *$ & .547 \\
\hline Area size $(\mathrm{Sq} . \mathrm{Km})$ & .001 & & .000 & -.000 & & .000 & .001 & & .000 \\
\hline Natural resources (Oil/gas rents) & -.001 & $* * *$ & .000 & -.001 & $* * *$ & .000 & -.001 & $* * *$ & .000 \\
\hline Social Structure & & & & & & & & & \\
\hline Linguistic fractionalization & -.878 & $* * *$ & .242 & -.196 & & .261 & -.628 & $*$ & .290 \\
\hline Religious fractionalization & -.450 & & .257 & -.448 & & .331 & -.259 & & .295 \\
\hline Human capital (secondary schooling) & -.011 & $* *$ & .005 & -.011 & & .005 & .008 & & .101 \\
\hline Logged population size & .568 & $* * *$ & .129 & .442 & $*$ & .194 & .546 & $* * *$ & .127 \\
\hline Internal conflict & -.015 & * & .241 & -.485 & $*$ & .262 & -.579 & $* *$ & .246 \\
\hline Cultural traditions & & & & & & & & & \\
\hline Muslim society & .510 & * & .344 & .300 & & .359 & .013 & & .336 \\
\hline British colonial legacy & .586 & $* * *$ & .166 & .678 & $* *$ & .208 & .549 & $* * *$ & .170 \\
\hline Global trends & & & & & & & & & \\
\hline Year & -.039 & $* * *$ & .013 & -.050 & $* * *$ & .013 & -.040 & $* * *$ & .012 \\
\hline $\begin{array}{l}\text { R-2 } \\
\text { Number of observations } \\
\text { Number of countries } \\
\text { Years }\end{array}$ & & $\begin{array}{c}.027 \\
3,071 \\
103 \\
32\end{array}$ & & & $\begin{array}{c}.031 \\
3,038 \\
102 \\
32\end{array}$ & & & $\begin{array}{c}.029 \\
3,071 \\
103 \\
32\end{array}$ & \\
\hline
\end{tabular}

Note: The models present the unstandardized beta coefficients and the statistical significance of Ordinary Least Squares linear regression models with Panel Corrected Standard Errors. The dependent variable is income per capita in purchasing power parity from the chain series index of the Penn World Tables. ${ }^{* *} \mathrm{p}<0.001,{ }^{* *} \mathrm{p}<0.001,{ }^{*} \mathrm{p}<0.05$. For details of all the variables, see the technical appendix. 
Appendix A: Description of the variables and data sources

\begin{tabular}{|c|c|}
\hline Name & Description and source \\
\hline Liberal Democracy index & $\begin{array}{l}\text { The Gastil index, the 7-point scale used by Freedom House, measuring political rights and civil liberties annually } \\
\text { since } 1972 \text {. The index is standardized to a 100-point scale. } \\
\text { Source: Freedom House. Freedom in the World www.Freedomhouse.com. }\end{array}$ \\
\hline Bureaucratic Governance & $\begin{array}{l}\text { Political Risk Service's Group (PRSG) International Country Risk Guide estimates of the Quality of Governance. } \\
\text { Based on expert assessments, the PRSG's Quality of Government index combines three components: (1) } \\
\text { Bureaucratic Quality; (2) Corruption, and; (3) Law and Order. The index is standardized to a } 100 \text { point scale. } \\
\text { Source: The Ouality of Government Dataset, the OOG Institute, University of Goteborg Mav } 2010 \text { release. }\end{array}$ \\
\hline Regime classification & $\begin{array}{l}\text { The regime classification is based on the liberal democracy index and the bureaucratic governance index which } \\
\text { are both standardized to } 100 \text { point scales and dichotomized around the mean to create a four-fold typology } \\
\text { distinguishing regimes which are bureaucratic democracies, bureaucratic autocracies, patronage democracies and } \\
\text { patronage democracies. For details see chapter } 4 \text { Pippa Norris. Democratic Governance and Human development: } \\
\text { Prosperity, Welfare and Peace (New York: Cambridge University Press, forthcoming 2012). }\end{array}$ \\
\hline Economic growth & $\begin{array}{l}\text { Annual percentage growth rate of per capita GDP based on constant local prices. } \\
\text { Source: Penn World Tables. }\end{array}$ \\
\hline Geographic location & $\begin{array}{l}\text { The absolute value of the latitude from the equator of the capital city, divided by } 90 \text { (to take values between } 0 \\
\text { and 1). Source: La Porta, Lopez-de-Silanes, Shleifer and Vishny } 1999\end{array}$ \\
\hline Internal armed conflict & $\begin{array}{l}\text { Internal armed conflict' is defined as that which occurs between the government of a state and one or more } \\
\text { internal opposition group(s) without intervention from other states. The UCDP measure is coded one a 4-point } \\
\text { ordinal scale depending upon the incidence and magnitude of conflict (depending upon the number of battle- } \\
\text { related deaths): (0) no interstate conflict; (1) minor interstate armed conflict; (2) Interstate intermediate armed } \\
\text { conflict; and (4) Interstate war. The measure is recoded into a binary dummy }(0 / 1) \text { variable indicating the } \\
\text { incidence of internal armed conflict above the minimum threshold irrespective of magnitude. } \\
\text { Source: UCDP/PRIO Armed Conflict Dataset V4.0 1946-2007 }\end{array}$ \\
\hline Income & $\begin{array}{l}\text { Per Capita GDP measured in constant international \$ in Purchasing Power Parity. Various years. } \\
\text { Source: Penn World Tables. }\end{array}$ \\
\hline Area size & Area of the nation-state in kilometers Source: Banks CNTS dataset \\
\hline Natural resources & $\begin{array}{l}\text { Natural resources are operationalized as oil and gas rents per capita. This represents the total annual value of a } \\
\text { country's oil and gas production, minus the extraction costs in each country, divided by its population to } \\
\text { normalize the value of the rents, measured from } 1960 \text { to } 2002 \text { in constant } 2000 \text { US dollars. } \\
\text { Source: Michael Ross (2004) }\end{array}$ \\
\hline Human capital & $\begin{array}{l}\text { Gross enrollment ratio in secondary education is the ratio of total enrollment, regardless of age, to the } \\
\text { population of the age group that officially corresponds to the secondary level of education. Secondary education } \\
\text { completes the provision of basic education that began at the primary level, and aims at laying the foundations for } \\
\text { lifelong learning and human development, by offering more subject- or skill-oriented instruction using more } \\
\text { specialized teachers. Source: World Development Indicators }\end{array}$ \\
\hline Muslim society & Predominant religious faith in each society. Source: CIA The World Factbook www.cia.gov \\
\hline Linguistic fractionalization & $\begin{array}{l}\text { The share of languages spoken as 'mother tongues' in each country, generally derived from national census data, } \\
\text { as reported in the Encyclopedia Britannica 2001. The fractionalization index is computed as one minus the } \\
\text { Herfindahl index of ethnolinguistic group share, reflecting the probability that two randomly selected individuals } \\
\text { from a population belonged to different groups. Source: Alesina, Devleeschauwer, Easterly, Kurlat and Wacziarg } \\
\text { 2003. }\end{array}$ \\
\hline Religious fractionalization & $\begin{array}{l}\text { The share of the population adhering to different religions in each country, as reported in the Encyclopedia } \\
\text { Britannica } 2001 \text { and related sources. The fractionalization index is computed as one minus the Herfindahl index } \\
\text { of ethnoreligious group share, reflecting the probability that two randomly selected individuals from a population } \\
\text { belonged to different groups. } \\
\text { Source: Alesina, Devleeschauwer, Easterly, Kurlat and Wacziarg } 2003 \text {. }\end{array}$ \\
\hline Trade Flows & Economic trade and investment flows Source: KOF (2008) \\
\hline Logged population size & This estimates the total population per state (thousands) (logged). Source: World Bank World Development Indicators. \\
\hline BritCol & $\begin{array}{l}\text { The past colonial history of countries was classified into those which shared a British colonial background (1), } \\
\text { and all others (0). Source: CIA The World Factbook www.cia.gov }\end{array}$ \\
\hline PR Electoral systems & $\begin{array}{l}\text { The type of electoral systems used for the lower house of the national parliament. Majoritarian formulas include } \\
\text { First-Past-the-Post, Second Ballot, the Block vote, the Single Non-Transferable Vote, and the Alternative Vote. } \\
\text { Proportional formulas are defined to include Party List as well as the Single Transferable Vote systems. } \\
\text { Combined (or 'mixed') formulas use both majoritarian and proportional ballots for election to the same body. } \\
\text { Countries using proportional formulas are coded into a dummy variable }(1 / 0) \text {. } \\
\text { Sources: International IDEA. Handbook of Electoral System design, } 2^{\text {nd }} \text { ed. 2005; Norris. 2008. Driving Democracy }\end{array}$ \\
\hline Federal state & $\begin{array}{l}\text { Federal states (coded 1) are either federations or decentralized unions. Federations are defined as compound } \\
\text { polities where the directly elected constituent units possess independent powers in the exercise of their } \\
\text { legislative, fiscal and administrative responsibilities. Decentralized unions are those where constituent units of } \\
\text { government work through the common organs of government although constitutionally-protected subunits of } \\
\text { government have some functional autonomy. All states which are not either federations or decentralized unions } \\
\text { are coded as unitary states (coded 0). } \\
\text { Sources: Norris. 2008. Driving Democracy, Watts. Comparing Federal Systems 1999, Banks, Muller and Overstreet. } \\
\text { Political Handbook of the World 2000-2002. }\end{array}$ \\
\hline Type of executive & $\begin{array}{l}\text { The type of executive was classified as parliamentary, mixed or presidential. Source: Norris. 2008. Driving } \\
\text { Democracy }\end{array}$ \\
\hline
\end{tabular}


Note: This paper is drawn from a larger book manuscript, "Democratic Governance and Human Development: Prosperity, Welfare and Peace" (New York: Cambridge University Press, forthcoming 2012). More details and draft chapters are available at www.pippanorris.com.

${ }^{1}$ Robert E. Hall and Charles I. Jones. 1999. 'Why do some countries produce so much more output per worker than others?' The Quarterly Journal of Economics 114(1): 83-116; Dani Rodrik, Arvind Subramanian, and Francesco Trebbi. 2004. 'Institutions rule: The primacy of institutions over geography and integration in economic development.' Journal of Economic Growth 9 (2): 131-165; Dani Rodrik. 2007. One Economics, Many Recipes. Princeton: Princeton University Press.

2 John Geering and Strom C. Thacker. 2004. 'Political institutions and corruption: The role of unitarism and parliamentarism.' British Journal of Political Science 34: 295-330; H.E. Sung. 2004. 'Democracy and political corruption: A cross-national comparison.' Crime, Law and Social Change 41: 179.

${ }^{3}$ Vasudha Chhotray and David Hulme. 2009. 'Contrasting Visions for Aid and Governance in the 21st Century: The White House Millennium Challenge Account and DFID’s Drivers of Change.' World Development 37(1): 36-49.

${ }^{4}$ Edward Newman and Roland Rich. Eds. 2004. The UN Role in Promoting Democracy. New York: United Nations University Press.

${ }^{5}$ http://www.undp.org/annualreport2011/democratic governance.html

${ }^{6}$ For literature reviews, see Hristos Doucouliagos, and Mehmet Ali Ulubasoglu. 2008. 'Democracy and economic growth: A meta-analysis.' American Journal of Political Science 52(1): 61-83; Sebastian Dellepiane-Avellaneda. 2009. 'Review article: Good governance, institutions and economic development: Beyond the conventional wisdom.' British Journal of Political Science 40: 195-224.

7 See, for example, Dani Rodrik, A. Subramanian, F. Trebbi. 2004. 'Institutions rule: The primacy of institutions over geography and integration in economic development.' Journal of Economic Growth 9 (2): 131-165.

${ }^{8}$ See, for example, Edward L. Glaeser, Rafael La Porta, Florencio Lopez-de-Silanes, and Andre Shleifer. 2004. 'Do institutions cause growth?' Journal of Economic Growth 9 (3): 271-303; Marcus J. Kurtz and Andrew Schrank. 2007. 'Growth and governance: Models, measures, and mechanisms.' Journal of Politics 69(2): 538-554; Daron Acemoglu, Simon Johnson, and James A. Robinson. 2008. 'Income and democracy.' American Economic Review 98(3): 808-842; Nicholas Charron and Victor Lapuente. 2010. 'Does democracy produce quality of government?' European Journal of Political Research 49: 443-470.

9 R. Levine and D. Renelt. 1992. 'A sensitivity analysis of cross-country growth regressions.' American Economic Review 82(4): 942-963; James L. Butkiewicz and Halit Yanikkaya. 2006. 'Institutional quality and economic growth: Maintenance of the rule of law or democratic institutions, or both?' Economic Modelling 23(4): 648-661.

10 For textbooks approaches, see, Robert J. Barro and Xavier Sala-i-Martin. 2003. Economic Growth. $2^{\text {nd }}$ Edition. Cambridge, MA: The MIT Press; Rick Szostak. 2009. The causes of economic growth: interdisciplinary perspectives. Heidelberg: Springer.

11 Douglas North. 1990. Institutions, Institutional Change and Economic Performance. Cambridge: Cambridge University Press; Dani Rodrik, A. Subramanian, F. Trebbi. 2004. 'Institutions rule: The primacy of institutions over geography and integration in economic development.' Journal of Economic Growth 9 (2): 131-165; R. Rigobon and Dani Rodrik. 2005. 'Rule of law, democracy, openness, and income: Estimating the interrelationships.' Economics of Transition 13 (3): 533-564.

12 See Daron Acemoglu, Simon Johnson, and James A. Robinson. 2001. 'The colonial origins of comparative development: an empirical investigation.' The American Economic Review 91 (5):1369-401; Daron Acemoglu, Simon Johnson, and James A. Robinson. 2002. 'Reversal of fortune: Geography and institutions in the making of the modern income distribution.' The Quarterly Journal of Econometrics 118:1231-94; Daron Acemoglu, and James A. Robinson. 2006. Economic Origins of Dictatorship and Democracy. New York: Cambridge University Press.

13 Marcus J. Kurtz and Andrew Schrank. 2007. 'Growth and governance: Models, measures, and mechanisms.' Journal of Politics 69(2): 538-554.

${ }^{14}$ Edward L. Glaeser, Rafael La Porta, Florencio Lopez-de-Silanes, and Andre Shleifer. 2004. 'Do institutions cause growth?' Journal of Economic Growth 9 (3): 271-303.

15 See Nicholas Charron and Victor Lapuente. 2010. 'Does democracy produce quality of government?' European Journal of Political Research 49: 443-470.

16 Sebastian Dellepiane-Avellaneda. 2009. 'Review article: Good governance, institutions and economic development: Beyond the conventional wisdom.' British Journal of Political Science 40: 195-224. 
17 Robert J. Barro. 1996. 'Democracy and growth.' Journal of Economic Growth 1 (1): 1-27; Robert J. Barro. 1997. Determinants of Economic Growth: A Cross-Country Empirical Study. Cambridge: The MIT Press.

18 Adam Przeworski, Michael E. Alvarez, José Antonio Cheibub, and Fernando Limongi. 1996. 'What makes democracies endure?' Journal of Democracy 7:1: 39-55; Adam Przeworski, and F. Limongi.1997. 'Modernization: theories and facts.' World Politics 49:155-183; Adam Przeworski, Michael E. Alvarez, José Antonio Cheibub, and Fernando Limongi. 2000. Democracy and Development: Political Institutions and Well-Being in the World, 1950-1990. New York: Cambridge University Press.

19 Adam Przeworski, Michael E. Alvarez, José Antonio Cheibub, and Fernando Limongi. 2000. Democracy and Development: Political Institutions and Well-Being in the World, 1950-1990. New York: Cambridge University Press

${ }^{20}$ Hristos Doucouliagos, and Mehmet Ali Ulubasoglu. 2008. 'Democracy and economic growth: A meta-analysis.' American Journal of Political Science 52(1): 61-83.

${ }^{21}$ See, for example, William Easterly. 2002. The Elusive Quest for Growth. Cambridge, MA: The MIT Press. Chapter 11 and 12 .

22 John Williamson. 1990. 'What Washington means for policy reform.' In Latin American Adjustment: How much has Happened? Ed. John Williamson. Washington DC: Institute for International Economics; J. Marangos. 2009. 'The evolution of the term 'Washington consensus.' Journal of Economic Surveys 23(2): 350-384.

23 John Williamson and Pedro-Pablo (Editors) 2003. After the Washington Consensus: Restarting Growth and Reform in Latin America. Peterson Institute; Francisco Panizz. 2009. Contemporary Latin America: Development and Democracy beyond the Washington Consensus. London: Zed Books.

${ }^{24}$ Ian Marsh, Jean Blondel and Takashi Inoguchi. Eds.1999. Democratic Governance and Economic Performance. New York: United Nations University Press; H. Z. Li and Z. H. Xu. 2007. 'Economic Convergence in Seven Asian Economies.' Review of Development Economics 11 (3): 531-49; F. K. W. Loh. 2008. 'Procedural Democracy, Participatory Democracy and Regional Networking: The Multi-Terrain Struggle for Democracy in Southeast Asia.' Inter-Asia Cultural Studies 9, (1): 127-41.

25 Joseph E. Stigletz. 2010. Freefall: America, Free Markets, and the Sinking of the World Economy. New York: W. W. Norton \& Company;

${ }^{26}$ John Williamson. 1990. 'What Washington means for policy reform.' In Latin American Adjustment: How Much has Happened? Ed. John Williamson. Washington DC: Institute for International Economics; J. Marangos. 2009. 'The evolution of the term 'Washington consensus.' Journal of Economic Surveys 23(2): 350-384.

27 Douglas North. 1990. Institutions, Institutional Change and Economic Performance. Cambridge: Cambridge University Press.

28 Paulo Mauro. 1995. 'Corruption and growth.' Quarterly Journal of Economics 110: 681-712.

${ }^{29}$ P. Bardhan. 1997. 'Corruption and development: A review of issues.' Journal of Economic Literature 35 (3): $1320-$ 1346; Susan Rose-Ackerman, Susan. 1999. Corruption and Government: Causes, Consequences and Reform. New York: Cambridge University Press; A. Brunetti and B. Weder. 2003. 'A free press is bad news for corruption.' Journal of Public Economics 87 (7-8): 1801-24; Alan Doig. 2000. Corruption and Democratization. London: Frank Cass.

30 Stephen Knack and Philip Keefer. 1995. 'Institutions and economic performance: Cross-Country tests using alternative institutional measures.' Economics and Politics 7(3): 207-27.

${ }^{31}$ Daniel Kaufmann, Aart Kraay, and Massimo Mastruzzi. 2010. The Worldwide Governance Indicators: Methodology and Analytical Issues. Washington, DC: The Brookings Institute. www.govindicators.org

32 Daniel Kaufmann, Aart Kraay, and Massimo Mastruzzi. 2007. Governance Matters VI: Aggregate and Individual Governance Indicators, 1996-2006. Washington DC: The World Bank, Policy Research Working Paper; Daniel Kaufmann, Aart Kraay, and Massimo Mastruzzi. 2007. 'Growth and governance: A rejoinder.' Journal of Politics 69 (2): $570-572$.

33 See Daron Acemoglu, Simon Johnson, and James A. Robinson. 2001. 'The colonial origins of comparative development: an empirical investigation.' The American Economic Review 91 (5):1369-401; Daron Acemoglu, Simon Johnson, and James A. Robinson. 2002. 'Reversal of fortune: Geography and institutions in the making of the modern income distribution.' The Quarterly Journal of Econometrics 118:1231-94; Daron Acemoglu, and James A. Robinson. 2006. Economic Origins of Dictatorship and Democracy. New York: Cambridge University Press.

${ }^{34}$ Dani Rodrik, A. Subramanian, F. Trebbi. 2004. 'Institutions rule: The primacy of institutions over geography and integration in economic development.' Journal of Economic Growth 9 (2): 131-165; R. Rigobon and Dani Rodrik. 2005. 
'Rule of law, democracy, openness, and income: Estimating the interrelationships.' Economics of Transition 13 (3): 533 564.

35 Joseph E. Stigletz. 1989. The Economic Role of the State. Oxford: Blackwell; Joseph E. Stigletz. 2006. Making Globalization Work. New York: W. W. Norton \& Company.

${ }^{36}$ Francis Fukuyama. 2004. State-Building: Governance and World Order in the $21^{\text {st }}$ Century. Ithaca, NY: Cornell University Press.

${ }^{37}$ Francis Fukuyama. 2004. State-Building: Governance and World Order in the $21^{\text {st }}$ Century. Ithaca, NY: Cornell University Press. pp.26-29.

38 Peter Evans and J.E. Rauch. 1999. 'Bureaucracy and growth: A cross-national analysis of the effects of 'Weberian' state structures on economic growth.' American Sociological Review 64(5): 748-765.

39 Alice Amsden. 1989. Asia's Next Giant. Oxford: Oxford University Press; Alice Amsden. 2001. The Rise of the 'Rest': Challenges to the West from Late-industrializing Economies. Oxford: Oxford University Press; Robert Wade. 1990. Governing the Market: Economic Theory and the Role of Government in East Asian Industrialization. Princeton: Princeton University Press; Francis Fukuyama. 2007. 'Liberalism versus state-building.' Journal of Democracy 18 (3):10-13; Young Whan Kihl. 2005. Transforming Korean politics: democracy, reform, and culture. Armonk, N.Y.: M.E. Sharpe.

${ }^{40}$ See Carl A. Trocki. 2006. Singapore: wealth, power and the culture of control. New York: Routledge; Diane K. Mauzy and R.S. Milne. 2002. Singapore politics under the People's Action Party. New York: Routledge.

${ }^{41}$ Gross domestic product based on purchasing-power-parity (PPP) per capita GDP, current international dollars, as estimated by the IMF. World Economic Outlook Database, April 2010. http://www.imf.org/external/pubs/ft/weo/2010/01/weodata/index.aspx

${ }^{42}$ Martin King Whyte. 2009. 'Paradoxes of China's economic boom.' Annual Review of Sociology 35: 371-392.

${ }^{43}$ David Kang. 2002. Crony Capitalism: Corruption and Development in South Korea and the Philippines New York: Cambridge University Press. The 2010 Corruption Perceptions Index by Transparency International, however, ranks the Republic of Korea as 39 th (best) out of 178 countries worldwide, placed in a similar ranking to Malta and Costa Rica.

http://www.transparency.org/policy research/surveys indices/cpi/2010/results

${ }^{44}$ Morton H. Halperin, Joseph T. Siegle, and Michael M. Weinstein. 2010. The Democracy Advantage: How Democracies Promote Prosperity and Peace. New York: Routledge. $2^{\text {nd }}$ edition. 15.

45 Francis Fukuyama. 2004. State-Building: Governance and World Order in the $21^{\text {st }}$ Century. Ithaca, NY: Cornell University Press.p28.

46 Anthony Downs. 1997. An Economic Theory of Democracy. New York: Addison Wesley; Morris Fiorina. 1981. Retrospective Voting in American National Elections New Haven: Yale; Michael S. Lewis-Beck. 1988. Economics \& Elections: The Major Western Democracies. Ann Arbor: University of Michigan Press.

${ }^{47}$ Michael S. Lewis-Beck. 1990. Economics and Elections: The Major Western Democracies. Ann Arbor: The University of Michigan Press; Christopher J. Anderson. 1995. Blaming the Government: Citizens and the Economy in Five European Democracies. New York: M.E. Sharpe; G. Bingham Powell and G.D. Whitten. 1993. 'A cross-national analysis of economic voting: Taking account of the political context.' American Journal of Political Science 37(2): 391-414; G. Bingham Powell. 2000. Elections as Instruments of Democracy. New Haven: Yale University Press.

${ }^{48}$ Wouter van der Brug, Cees van der Eijk and Mark Franklin. 2007. The Economy and the Vote: Economic Conditions and Elections in Fifteen Countries. Cambridge: Cambridge University Press.

49 Donald Wittman. 1995. The Myth of Democratic Failure. Chicago: University of Chicago Press.

${ }^{50}$ Morton H. Halperin, Joseph T. Siegle, and Michael M. Weinstein. 2010. The Democracy Advantage: How Democracies Promote Prosperity and Peace. New York: Routledge. $2^{\text {nd }}$ edition. P.48.

51 Morton H. Halperin, Joseph T. Siegle, and Michael M. Weinstein. 2010. The Democracy Advantage: How Democracies Promote Prosperity and Peace. New York: Routledge. $2^{\text {nd }}$ edition p. 32.

${ }^{52}$ Guillermo O'Donnell. 1979. Modernization and Bureaucratic-Authoritarianism Studies in South American Politics. Berkeley, CA: Institute of International Studies, University of California.

53 Robert J. Barro. 1997. Determinants of Economic Growth: A Cross-Country Empirical Study. Cambridge: The MIT Press. 
${ }^{54}$ Matthew A. Baum and David A. Lake. 2003. 'The political economy of growth: Democracy and human capital.' American Journal of Political Science 47 (2): 333-347; David S. Brown and Wendy Hunter. 2004. 'Democracy and human capital formation.' Comparative Political Studies 37(7): 842-64.

55 Morton H. Halperin, Joseph T. Siegle, and Michael M. Weinstein. 2010. The Democracy Advantage: How Democracies Promote Prosperity and Peace. New York: Routledge. $2^{\text {nd }}$ edition. P.39.

${ }^{56}$ Robert J. Barro, 2001. 'Human capital and growth.' American Economic Review 91(2): 12-17.

${ }^{57}$ Robert J. Barro, 1999. 'Determinants of democracy.' Journal of Political Economy 107 (6): 158-183.

58 Pippa Norris. 2004. Electoral Engineering. New York: Cambridge University Press. Chapter 4; Pippa Norris. 2009. Driving Democracy. New York: Cambridge University Press.

59 Arend Lijphart. 1999. Patterns of Democracy. New Haven, CT: Yale University Press; Peter Cowhey and Stephen Haggard. 2001. Presidents, Parliaments and Policy. Cambridge: Cambridge University Press; Torsten Persson and Guido Tabellini. 2003. The Economic Effects of Constitutions. Cambridge, MA: The MIT Press; Carl Henrik Knutsen. 2011. 'Which democracies prosper? Electoral rules, form of government and economic growth.' Electoral Studies 30(1): 8390; Stefan Voigt. 2011. 'Positive constitutional economics II: A survey of recent developments.' Public Choice 146(12): 205-256

60 Torsten Persson and Guido Tabellini. 2003. The Economic Effects of Constitutions. Cambridge, MA: The MIT Press; Torsten Persson and Guido Tabellini. 2004. 'Constitutions and economic policy.' Journal of Economic Perspectives 18: 7598; Torsten Persson. 2006. 'Democracy and development: The devil in the details.' American Economic Review 96: 319.

${ }^{61}$ Carl Henrik Knutsen. 2011. 'Which democracies prosper? Electoral rules, form of government and economic growth.' Electoral Studies 30(1): 83-90.

62 Pippa Norris. 2004. Electoral Engineering. New York: Cambridge University Press.

63 John Geering and Strom C. Thacker. 2004. 'Political institutions and corruption: The role of unitarism and parliamentarism.' British Journal of Political Science 34: 295-330.

${ }^{64}$ Christopher D. Anderson. 2006. 'Economic voting and multilevel governance: A comparative individual-level analysis.' American Journal Of Political Science 50: 449+; M.A. Kayser and Christopher Wlezien. 2011. 'Performance pressure: Patterns of partisanship and the economic vote.' European Journal of Political Research 50(3): 365-394.

65 Arend Lijphart. 1999. Patterns of Democracy. New Haven: Yale University Press.

66 Yi Feng. 2003. Democracy, Governance and Economic Growth: Theory and Evidence. Cambridge, MA: The MIT Press

${ }^{67}$ For more details about this argument, see chapter 2. Pippa Norris. Democratic Governance and Human development: Prosperity, Welfare and Peace New York: Cambridge University Press (forthcoming 2012).

${ }^{68}$ Pippa Norris. 2011. Democratic Deficit. New York: Cambridge University Press.

${ }^{69}$ Daron Acemoglu, Simon Johnson, and James A. Robinson. 2008. 'Income and democracy.' American Economic Review 98(3): 808-842.

70 Seymour Martin Lipset. 1959. 'Some social requisites of democracy: Economic development and political legitimacy.' American Political Science Review. 53: 69-105.

71 See also Dankwart Rustow. 1970. 'Transitions to democracy.' Comparative Politics 2: 337-63.

72 Daron Acemoglu, Simon Johnson, and James A. Robinson. 2008. 'Income and democracy.' American Economic Review 98(3): 808-842. See also Edward L. Glaeser, Rafael La Porta, Florencio Lopez-de-Silanes, and Andre Shleifer. 2004. 'Do institutions cause growth?' Journal of Economic Growth 9 (3): 271-303.

${ }^{73}$ David Dollar and V. Levine. 'The increasing selectivity of foreign aid, 1984-2003.' World Development 34(12): $2034-$ 2046.

${ }^{74}$ See, however, Torsten Persson, and Guido Tabellini. 2003. The Economic Effects of Constitutions. Cambridge, MA: The MIT Press; Torsten Persson. 2006. 'Democracy and development: The devil in the details.' American Economic Review 96: 319.

75 Geraldo L. Munck. 2009. Measuring Democracy: A Bridge between Scholarship and Politics. Baltimore: The Johns Hopkins Press.

${ }^{76}$ Anne Mette Kjaer. 2010. Governance. Cambridge: Polity Press. 
77 Marcus J. Kurtz and Andrew Schrank. 2007. 'Growth and governance: Models, measures, and mechanisms.' Journal of Politics 69(2): 538-554; C.R. Apaza. 2009. 'Measuring governance and corruption through the worldwide governance indicators: Critiques, responses, and ongoing scholarly discussion.' PS-Political Science \& Politics 42(1): $139-143$

78 Stephen Haggard and Lydia Tiede. 2011. 'The rule of law and economic growth: where are we?' World Development 39 (5): 673-685.

${ }^{79}$ For details see chapter 4 Pippa Norris. Democratic Governance and Human development: Prosperity, Welfare and Peace New York: Cambridge University Press (forthcoming 2012).

80 Alan Heston, Robert Summers and Bettina Aten, Penn World Table Version 7.0, Center for International Comparisons of Production, Income and Prices at the University of Pennsylvania, May 2011. http://pwt.econ.upenn.edu/php site/pwt index.php

${ }^{81}$ Institutions are classified from Pippa Norris. 2009. Driving Democracy. New York: Cambridge University Press.

${ }^{82}$ Nicholas Charron and Victor Lapuente. 2010. 'Does democracy produce quality of government?' European Journal of Political Research 49: 443-470.

${ }^{83}$ Jared M. Diamond. 1999. Guns, Germs, and Steel: The Fates of Human Societies. New York: W.W. Norton.

${ }^{84}$ William Easterly and R. Levine.1997. 'Africa's growth tragedy: Policies and ethnic divisions.' Quarterly Journal of Economics 111 (4): 1203-1250.

${ }^{85}$ Macartan Humphreys, Jeffrey D. Sachs, and Joseph E. Stiglitz. Eds. 2007. Escaping the Resource Curse. New York: Columbia University Press.

86 William Easterly. 2002. The Elusive Quest for Growth. Cambridge, MA: The MIT Press. Chapter 4.

87 Peter Evans and J.E. Rauch. 1999. 'Bureaucracy and growth: A cross-national analysis of the effects of 'Weberian' state structures on economic growth.' American Sociological Review 64(5): 748-765.

88 Morton H. Halperin, Joseph T. Siegle, and Michael M. Weinstein. 2010. The Democracy Advantage: How Democracies Promote Prosperity and Peace. New York: Routledge. $2^{\text {nd }}$ edition. P.39.

${ }^{89}$ Robert J. Barro. 1997. Determinants of Economic Growth: A Cross-Country Empirical Study. Cambridge: The MIT Press; Adam Przeworski, Michael E. Alvarez, José Antonio Cheibub, and Fernando Limongi. 2000. Democracy and Development: Political Institutions and Well-Being in the World, 1950-1990. New York: Cambridge University Press; Hristos Doucouliagos, and Mehmet Ali Ulubasoglu. 2008. 'Democracy and economic growth: A meta-analysis.' American Journal of Political Science 52(1): 61-83.

90 Jose Maria Maravall and Ignacio Sanchez-Cuenca. Eds. 2008. Controlling Governments: Voters, Institutions and Accountability. New York: Cambridge University Press.

91 Torsten Persson and Guido Tabellini. 2004. 'Constitutions and economic policy.' Journal of Economic Perspectives 18(1): 75-98.

${ }^{92}$ Henrik Knutsen. 2011. 'Which democracies prosper? Electoral rules, form of government and economic growth.' Electoral Studies 30(1): 83-90.

93 William Easterly. 2002. The Elusive Quest for Growth. Cambridge, MA: The MIT Press. Chapter 4. 